\title{
How did the Sarbanes-Oxley Act affect managerial incentives? Evidence from corporate acquisitions
}

\author{
David Hillier $^{1} \cdot$ Patrick McColgan $^{2} \cdot$ Athanasios Tsekeris $^{3}$
}

Accepted: 12 November 2021 / Published online: 10 December 2021

(C) The Author(s) 2021

\begin{abstract}
We examine the impact of incentive compensation on the riskiness of acquisition decisions before and after the passage of the Sarbanes-Oxley Act (SOX). Before SOX, equity-based compensation was positively related to changes in risk around acquisition decisions, but this relationship weakened after the introduction of SOX. The drop in post-SOX acquisition-related risk stems from how managers respond to compensation-based incentives in the new regulatory environment. We show that executive stock options and pay-risk sensitivity drive post-SOX managerial responsiveness to risk-taking incentives. We also document a post-SOX value-enhancing effect on long-term stock-price performance and total factor productivity through these same incentive compensation mechanisms. The results are robust to selection bias, simultaneity, measurements of risk, and the definition of incentive compensation.
\end{abstract}

Keywords Executive compensation - Managerial incentives $\cdot$ Acquisition risk $\cdot$ SarbanesOxley Act $\cdot$ Corporate governance

JEL Classification G32 · G34 · G38 · M12

The authors would like to thank Jens Hagendorff, Andrew Marshall, Helena Pinto, Jie Yang, and seminar participants at the 2014 EAA Annual Congress (Tallinn), 2014 FMA Annual Meeting (Nashville) and 2017 International Conference of the Financial Engineering and Banking Society (Glasgow) for their comments and feedback. All errors are our own.

Patrick McColgan

patrick.mccolgan@strath.ac.uk

David Hillier

david.hillier@strath.ac.uk

Athanasios Tsekeris

athanasios.tsekeris@gcu.ac.uk

1 Strathclyde Business School, University of Strathclyde, Glasgow G4 0GE, UK

2 Department of Accounting and Finance, University of Strathclyde, Glasgow G4 0QU, UK

3 Department of Finance, Accounting and Risk, Glasgow Caledonian University, Glasgow G4 0BA, UK 


\section{Introduction}

The Sarbanes-Oxley Act (SOX), enacted July 30, 2002, imposed the requirement that both Chief Executive and Chief Financial Officer certify the accuracy of financial statements (SOX, Section 302) and provide information on the adequacy of their internal controls (SOX, Section 404). Since willful violation of SOX attracts criminal charges, corporate compliance and executive personal costs have increased (Bargeron et al. 2010; Arping and Sautner 2013; Gao and Zhang 2019; Bloomfield 2021). SOX is also associated with a reduction in incentives to undertake risky investment projects (Carter et al. 2009; Chang et al. 2012; Cohen et al. 2013; Tang 2014; Kwon et al. 2019).

Despite the documented decrease in corporate risk-taking, SOX does not appear to be a panacea for resolving misaligned executive risk incentives, as suggested by the recent cases of Wells Fargo and Equifax (Bhagat and Bolton 2019). In this paper, we examine the impact of SOX on executive risk-taking incentives by investigating corporate acquisitions. Rather than focusing on the propensity to engage in risky investments, we examine the riskiness of investment decisions themselves by focusing on changes in firm risk surrounding an acquisition. We seek to understand how managerial compensation incentives changes firm risk surrounding acquisitions before and after enactment of SOX. Using SOX as a significant exogenous shock (Hege et al. 2021) allows us to examine how regulation can change managerial incentives to bear corporate and personal risk.

Regulatory scrutiny and litigation costs imposed by SOX have reduced the risk-tolerance of corporate executives (Bargeron et al. 2010). However, Leuz and Wysocki (2016) are critical of earlier studies whose findings can be explained by confounding events, and propose that studies make use of cross-sectional variation in sample companies to isolate a causal effect of SOX on corporate outcomes. We exploit cross-sectional variation in executive compensation incentives and consider how executives respond to these incentives through changes in the riskiness of investment decisions surrounding SOX. In addition to the previously documented decline in compensation incentives (Chang et al. 2012; Tang 2014) and risky investment (Bargeron et al. 2010), we propose that managers respond less positively to risk-taking incentives through compensation contracts after the introduction of SOX. We expect that this diminished the previously documented positive relation between equity-based compensation and managerial incentives to undertake risky investment projects (Agrawal and Mandelker 1987; Datta et al. 2001; Coles et al., 2006).

We focus on mergers and acquisitions (M\&As) since they are one of the most valuerelevant investment decisions managers can undertake that have clear announcement and effective dates to directly measure changes in risk surrounding the event. In addition, acquisition decisions can intensify the agency relationship between managers and shareholders and accentuate the impact of managerial incentives (Zhao 2013). Yermack (2006) argues it is better to examine one-time events to understand the impact of compensationbased managerial incentives. Harford and Li (2007) also show that post-acquisition stock price performance affects the sensitivity of CEO wealth to stock price movements. In contrast, they find no such relation between stock price performance and CEO wealth in the case of large capital expenditures.

Our paper makes several important contributions to the literature. First, we show that the documented decline in risk-taking activity post-SOX (Bargeron et al. 2010; Gao and Zhang 2019; Hege et al. 2021) did not come solely from changes in executive compensation structure (Chang et al. 2012; Cohen et al. 2013; Tang 2014) but can be explained by a change in the way executives respond to risk-taking incentives after the passage of the 
Act. For the pre-SOX period, we find a positive relation between managerial compensation incentives and post-acquisition changes in risk. This is consistent with earlier research that shows executive stock options incentivize managers to make riskier M\&A decisions (Datta et al. 2001) by increasing the convexity of managerial payoffs (Agrawal and Mandelker 1987; Coles et al. 2006). However, in the post-SOX period we find a significant weakening in the compensation-risk relationship. After accounting for changes in executive compensation, our results show that post-SOX executives are less responsive to risk-taking incentives, resulting in a decrease in the riskiness of acquisition investments. In robustness tests, we show that managers have become less responsive to risk-taking incentives even for the sub-sample of firms that increased incentive compensation post-SOX. This is a novel finding regarding the transmission mechanism of reduced risk-taking, post-SOX. For instance, Chen et al. (2015) show that the positive relation between executive risk-taking incentives and audit fees weakens post-SOX. However, they attribute this to the lower possibility of financial misreporting in the post-SOX period without providing empirical evidence of reduced corporate risk-taking in relation to managerial incentives. Similarly, Liu et al. (2020) associate the reduction in corporate risk-taking with the compensation clawback provisions that were initiated post-SOX but they do not examine the role of incentive compensation in this mechanism or the response of managers to risk-taking incentives post-SOX.

Second, we show that how managers respond to risk-taking incentives post-SOX is driven by their option portfolio. Based on the previously documented positive relation between risk-seeking behavior and convex payoffs from executive stock options (Coles et al. 2006; Gormley et al. 2013) we examine a rich set of managerial incentives including new stock option grants, previously granted unexercised options and total pay-risk sensitivity (Vega). We find that decreased managerial responsiveness remains significant across all option portfolio specifications. On the other hand, we find the managerial common stock portfolio does not have a major effect on any change in risk-taking activity post-SOX.

Third, previous studies document a significant decrease in risky investments, post-SOX (Bargeron et al. 2010; Kang et al. 2010). We complement this research by showing that managers select projects of significantly lower risk compared to the pre-SOX period even if they have been provided with risk-taking incentives.

Finally, we show that the change in responsiveness of acquiring managers to risk-taking incentives has a value-enhancing effect on long-run total factor productivity and shareholder wealth, primarily through the managerial option portfolio. These findings indicate the prevalence of a potentially excessive level of risk-taking before SOX with the mitigating impact of the Act on managerial risk appetite being beneficial to shareholders.

Our results are robust to controls for selection bias, alternative risk and incentive compensation specifications, controls for the impact of SOX on board governance, and endogeneity. We also control for confounding events that could affect acquirer risk and address concerns about causality between executive compensation and firm risk.

The empirical evidence suggests that although firms changed the structure of their executive compensation contracts post-SOX, corporate executives also changed the way in which they responded to the risk-taking incentives provided by equity-related compensation. Our results have important implications for regulators, policy makers, remuneration committees and investors. The passage of new regulation can change the way internal governance mechanisms affect corporate decisions reinforcing the regulators' intended impact on corporate policies. Our results show that the effect of SOX is not absorbed immediately but has a long-lasting impact on the responsiveness of managers to risk-taking incentives and subsequent decision making. Policy makers and remuneration committees should take 
into consideration the time horizon of proposed reforms which can have further implications for investors' risk level of aversion and investment horizon.

We organize the rest of the paper as follows. Section 2 reviews the literature. Section 3 outlines the data sample and discusses our research design. Section 4 presents and discusses the empirical results. Section 5 provides further robustness checks. Section 6 examines the impact of acquisition risk on deal performance and Sect. 7 concludes.

\section{Literature review}

\subsection{Incentive compensation and risk-seeking incentives}

Incentive compensation is widely considered an effective mechanism to influence managerial risk aversion and mitigate agency costs. Smith and Stulz (1985) note that if firms fail to provide managers with appropriate incentives via their compensation contract they are likely to forego positive net present value projects that increase firm risk. This risk-aversion conflict is particularly relevant to firms with high growth opportunities (Smith and Watts 1992; Guay 1999).

Supporting this theoretical view, Hirshleifer and Suh (1992) find a positive link between option-based compensation and R\&D expenditures. Rogers (2002) documents a strong negative relation between the use of derivatives for hedging purposes and risk-taking incentives provided by management stock and option holdings. Francis et al. (2017) finds that exchange rate exposure increases with pay-risk sensitivity, and Boone et al. (2011) show that CEO equity incentives are negatively related to the equity risk premium, which they attribute to the incentive alignment properties of stock options.

Focusing specifically on M\&A transactions, Agrawal and Mandelker (1987) find that executive stock and options holdings are positively associated with changes in the variance of acquirer stock returns surrounding the deal announcement. Datta et al. (2001) report that managers with high equity-based compensation make riskier M\&A decisions relative to managers with weaker equity incentives and Hagendorff and Vallascas (2011) show that higher pay-risk sensitivity leads to greater risk-inducing acquisitions in the banking sector. Along the same lines, Gormley et al. (2013) argue that managers with less convex payoffs tend to engage in more diversifying acquisitions that reduce firm risk.

Recent studies directly analyze the underlying pay-performance (Delta) and pay-risk (Vega) sensitivity of compensation contracts and their impact on corporate decision-making. Vega is positively related to risky investment spending (Nam et al. 2003; Coles et al. 2006; Brockman et al. 2010; Chava and Purnanandam 2010, Croci and Petmezas 2015) and is negatively related to investment in tangible assets and cash balances (Nam et al. 2003; Coles et al. 2006; Chava and Purnanandam 2010). On the other hand, the same studies show that Delta is positively correlated with cash holdings and managerial risk aversion and negatively correlated with risky investments, leverage, and stock return volatility.

These studies highlight that not all forms of equity-related compensation are equally effective in inducing risk-taking. We expect the effectiveness of stock options and related incentives to mitigate risk-aversion is greater than that of common stock, given the convex nature of their payoffs (Guay 1999; Nohel and Todd 2005; Coles et al. 2006). This is emphasized in the findings of Billett et al. (2010), who show that while high Vega induces managers to take more risk, high Delta promotes managerial risk-aversion. Bhagat and Bolton (2019) also find a negative relation between director stock ownership and bank risk. 


\subsection{SOX and risk-seeking incentives from executive compensation}

The introduction of SOX and the resulting increased liability on executive directors has had an adverse impact on managerial incentives to engage in risky investment projects. SOX has led to a significant reduction in risk-taking activity (Bargeron et al. 2010; Kang et al. 2010), corporate credit spreads (Nejadmalayeri et al. 2013), risk asymmetry (Bloomfield 2021), exchange rate exposure (Francis et al. 2017; Hege et al. 2021), firm opaqueness (Arping and Sautner 2013), and corporate innovation (Shadab 2008; Gao and Zhang 2019). On the other hand, Pryshchepa (2021) reports an increase in risky but value-enhancing investments post-SOX.

SOX is further associated with a change in the structure of managerial compensation incentives that leads managers to undertake risky investment projects. Both Chang et al. (2012) and Tang (2014) report a decline in pay-performance sensitivity and the use of executive stock options post-SOX. Carter et al. (2009) show that post-SOX, firms placed more weight on earnings in bonus contracts. A recent study by Kwon et al. (2019) confirms that SOX has increased firm conservatism and led to revisions in executive compensation contracts that reduces pay-performance sensitivity. Along the same lines, Benson et al. (2019) find a reduced role of Delta in compensation post-SOX. Cohen et al. (2013) show that SOX led to a reduction in the sensitivity of corporate investment to executive compensation.

Following Bargeron et al. (2010) we expect that SOX led to an overall reduction in the riskiness of corporate acquisitions, as measured by the post-acquisition change in firm risk. However, Leuz and Wysocki (2016) are critical that general studies of SOX outcomes are contaminated by confounding events. They argue that researchers should focus on such cross-sectional variation in sample firms to isolate a causal effect of SOX on corporate outcomes, including for our study the effect on corporate investment. To address this concern, we exploit cross-sectional variation in management compensation incentives and propose three compensation focused outcomes from SOX.

First, given the positive relation between equity-based pay and investment risk (Agrawal and Mandelker 1987; Datta et al. 2001), we expect the reduction in acquisition risk is concentrated in firms that offer larger equity-based pay components to top management. This can arise because of the general reduction in compensation incentives documented in Chang et al. (2012) and Tang (2014) among others. However, we extend this and propose that SOX has changed the way managers respond to risk-taking incentives. Vallascas and Hagendorff (2013) show that differences in the regulatory environment affect the way managers respond to incentives embedded in cash bonuses. We argue that the increased personal accountability and legal liabilities of managers in the post-SOX environment have changed the way managers react to compensation incentives that encourage risky investment. This weakens the previously documented positive relation between incentive compensation and riskiness of acquisition decisions (Agrawal and Mandelker 1987; Datta et al. 2001).

Second, we predict that the change in the relation between equity incentives and risktaking is driven by the executives' option portfolio. This stems from the fact that different forms of equity-based compensation affect risk-taking in different ways. Previous studies have shown that the convexity of payoffs inherent in executive stock options and, subsequently, the pay-risk sensitivity (Vega) of the option portfolio are positively related to risk-increasing activity (Guay 1999; Datta et al. 2001; Coles et al. 2006; Cohen et al. 2013). In contrast, restricted stock grants are less efficient in controlling managerial 
risk aversion (Smith and Watts 1982) and the pay-performance sensitivity (Delta) of the stock portfolio can potentially promote risk avoidance (Nohel and Todd 2005; Bhagat and Bolton 2019). Therefore, if SOX has changed the way managers respond to risktaking incentives, we expect this change to stem from a weakening in the efficiency of executive stock options to control managerial risk aversion.

Finally, we examine the effect of SOX on the relation between compensation incentives and the long-run wealth effects of acquisitions. Excessive risk-taking can be value destroying for acquiring shareholders (Moeller et al. 2005; Bouwman et al. 2009). Our discussion that SOX reduces the positive relation from equity-based compensation to risky investment benefits shareholders only if the change in risk-seeking activity during the post-SOX period is specifically restricted to those value-destroying risky investments that were a feature of the pre-SOX dotcom period highlighted in Moeller et al. (2005). By reducing the risk-taking appetite of acquiring managers stemming from their equity-based incentives, we propose that SOX has also improved the impact of these incentives on the performance of acquisition decisions.

\section{Data and research design}

\subsection{Sample selection criteria}

We use SDC Platinum to identify all completed US mergers and acquisitions with an announcement and effective date between January 1, 1993 and December 31, 2010. ${ }^{1}$ Following Aktas et al. (2013), only those transactions classified as mergers, acquisitions, acquisition of majority interests, acquisition of assets, acquisition of certain assets, acquisition of remaining interests, and exchange offers are included in our sample. The transaction must have a disclosed deal value of at least $\$ 1$ million $^{2}$; both the bidder ${ }^{3}$ and target should be US firms; the acquirer should be a publicly listed company owning less than $50 \%$ of the target's shares six months prior to the announcement and acquiring at least $50 \%$ of the target's shares in the transaction. These criteria result in a sample of 28,751 transactions.

We match these transactions to firms in the Standards and Poor's ExecuComp database for executive compensation data. ExecuComp provides compensation data on the top five highest compensated executives for firms in the S\&P 1500 Index. We require the acquiring firm to have executive compensation data available for the year preceding the acquisition announcement to reflect compensation incentives at the time of undertaking the acquisition and to remove changes in compensation following the acquisition. Since ExecuComp begins in 1992, the start date of our sample is 1993. Merging with Execucomp reduces the

\footnotetext{
1 In robustness tests, we repeat our multivariate analysis confining our sample to a 10 -year period surrounding the SOX (1997-2007) to avoid the impact that other confounding events may have on our results when the sample period covers an expanded time window. We obtain qualitatively similar results that are available in Online Appendix Tables 4a-9a and 11a.

2 All values in the analysis are adjusted for inflation and expressed in 2010 USD based on the consumer price index. We repeat the analysis including in our sample only those deals with a value higher than \$25 million. The results are available in Online Appendix Tables $4 \mathrm{~b}-9 \mathrm{~b}$ and $11 \mathrm{~b}$ and show that our findings are not driven by small deals.

3 We use the terms acquirer and bidder or acquiring and bidding firm interchangeably since all transactions in the sample are completed mergers and acquisitions.
} 
sample to 8179 transactions. We end the sample in 2010 as we expect any SOX-related impact on managerial incentives to be fully incorporated by then.

We also require the bidder to have accounting data in Compustat and stock price data in CRSP to enable us calculate changes in firm risk. This produces a final sample of 7747 acquisitions made by 1908 US firms. Unless otherwise stated, we measure all financial data at the year-end prior to the acquisition announcement.

\subsection{Sarbanes-0xley and incentive compensation variables}

We partition our sample into two sub-periods, the Pre-SOX and Post-SOX period, based on whether the acquisition announcement date is before or after the enactment of SOX (July $30,2002)$. In multivariate tests, we define SOX as a dummy variable that takes the value of one if the acquisition announcement date is after the enactment of SOX, and zero otherwise. We define all variables in Table 14.

We define New_Grants as the Black-Scholes fair value of new option and restricted stock grants awarded to the top five executives during the financial year divided by total compensation. Since previous studies show that stock options induce risk-taking activity more effectively than restricted stock (Smith and Watts 1982; Guay 1999) we further split this incentive measure between options and restricted stock components. New_OptionG measures the fair value of new executive stock options and New_StockG measures the fair value of new restricted stock grants, both scaled by total compensation.

Confining the analysis to new incentive awards ignores the potential impact of previously awarded incentives on managerial behavior. As managerial incentives stem from both new and previously awarded stock and option grants (Guay 1999) we also consider the incentive effect of all equity-based awards to the top five executives. New restricted stock and option grants typically do not vest immediately, ${ }^{4}$ meaning that previously granted incentives could have a stronger impact on investment decisions today. In addition, if executives have been granted higher than optimal equity incentives in the preceding years, new incentives should be adjusted downwards (Core and Guay 1999). We define Accum_Incentives as the sum of unexercised (vested and unvested) stock options and unvested restricted stock held by the top five executives divided by the total number of shares outstanding. As with New_Grants, we decompose Accum_Incentives between option and stock grants. Unex_Options is the ratio of unexercised stock options divided by the total number of shares outstanding and Unvest_Stock is the ratio of unvested restricted stock grants to total shares outstanding.

Nevertheless, compensation measures such as the volume and value of stock and option grants may not capture efficiently the impact of equity incentives on managerial wealth (Core and Guay 2002; Coles et al. 2006). In order to control for this potential bias, we also estimate Delta and Vega of stock and option portfolio as alternative and more direct measures of managerial incentives. We define Delta as the dollar change in top-5 executives' wealth for a $1 \%$ change in the firm's stock price and Vega as the dollar change in top-5 executives' wealth for a $1 \%$ change in the standard deviation of the firm's stock returns. The calculation of Delta and Vega follows the method developed by Core and Guay (2002) and Coles et al. (2006) based on the Black-Scholes (1973) model, as modified by Merton

\footnotetext{
4 Malmendier and Tate (2008) report that executive stock options have an average life span of ten years and they do not become fully exercisable until four years after the granting date.
} 
(1973) to account for dividends. We also control for the effect of the non-equity related compensation on managerial behavior. Research shows that cash pay can increase managerial entrenchment and risk aversion, and have a negative impact on firm performance (Brick et al. 2006; He 2012). We define Cash_Comp as the sum of salary and cash bonus payments to the top five executives of the acquiring firm scaled by total compensation.

\subsection{Volatility of acquirer returns}

We define acquisition risk as the change in acquiring firm's total risk surrounding the effective date. $D \_$Risk is the difference between the post- $(+1$ to +126 days $)$ and pre- $(-126$ to -1 days) acquisition standard deviation of stock returns. A positive value indicates an increase in total firm risk after the acquisition while a negative value means that the volatility of stock returns has fallen in the post-acquisition period.

In robustness tests, a second risk variable is constructed following Agrawal and Mandelker (1987) and Kravet (2014). The variable, D_Risk_AbR, measures the difference between the post-effective date ( +60 to +185 days) and pre-announcement date $(-185$ to -60 days) standard deviation of abnormal stock returns. The pre-acquisition period ends 60 trading days before the announcement date and the post-acquisition period begins 60 trading days after the effective date to minimize the impact of acquisition negotiation and completion periods on stock return volatility (Kravet 2014). For this measure, we calculate abnormal stock returns as the residual from the market model using the CRSP valueweighted index.

\subsection{Confounding events}

The period surrounding the passage of SOX is characterized by a number of confounding events that limit the ability of researchers to attribute their findings to the Act (Leuz and Wysocki 2016). Among the most important of these were the collapse of the internet bubble in 2001, the passage of SFAS No. 123R (Accounting for Stock-Based Compensation), and the 2007-2008 global financial crisis. ${ }^{5}$ We control for these events to sharpen the focus of our own results on the passage of SOX.

Cohen et al. (2013) cite evidence that the strongest impact of the internet crash on US firms occurred between August 2000 and August 2001. Therefore, we form a subsample of acquiring firms that made an acquisition announcement within the years 2000 and 2001. Similar to Cohen et al. (2013), we calculate stock price returns for the bidder subsample from August 1, 2000 to August 31, 2001. We then allocate acquiring firms in this subsample to deciles based on their stock price performance for that period. Based on this method, we define Internet_Crash as a categorical variable that takes values from 1 to 10 for acquiring firms with an acquisition announcement date between 2000 and 2001, and zero for any other acquirer. Firms in the worst performing decile, and who are therefore most affected by the market downturn, are assigned values of 10 . We use a similar approach to control for the global financial crisis. We build subsamples of acquirers with an acquisition announcement date in 2007, 2008 and 2009 and create a Financial_Crisis categorical variable that

\footnotetext{
5 We do not control for the 9/11 terrorist attack since Bargeron et al. (2010) show that the decrease in risk-taking activity in the post-SOX period cannot be explained by any uncertainty about the US economy caused by this event.
} 
takes values from 1 to 10 based on bidder's stock price performance, and zero for any deal outside the period 2007-2009. If these market downturns, rather than SOX, drive changes in compensation incentives and acquisition risk, we should find no relation between SOX and acquisition risk after controlling for the relevant market downturn.

The Financial Accounting Standard Boards introduced SFAS No. 123R in 2006 and required that costs associated with equity-based compensation must be fully expensed in the firm's financial statements. One of the consequences of this regulation is the decrease in option-based compensation by public firms (Brown and Lee 2007). Since option grants are associated with higher incentives for risk-increasing activity, we expect a decrease in the riskiness of firm acquisitions after the passage of SFAS No. 123R. The effective date implemented by the Securities and Exchange Commission (SEC) is the first fiscal quarter of the first fiscal year after June 15, 2005. Thus, we define SFAS_123R as a dummy variable set equal to one if the acquisition announcement takes place in 2006, and zero otherwise.

\section{Empirical results}

\subsection{Changes in risk and compensation around M\&As}

Table 1 presents the sample time-series distribution and summary statistics for the main risk and compensation variables and classifies them into pre- and post-SOX periods. M\&A activity increased in the late 1990s prior to the internet crash in 2000 (see Moeller et al. 2004; Masulis et al. 2007) and declines in the aftermath of the 2001 and 2008 recessions.

The results presented in Table 1 highlight a decline in acquisition risk post-SOX reflecting the high personal costs imposed by the Act on managers for undertaking risky investments (Bargeron et al. 2010). Although managers appear less risk averse before SOX, after 2001 D_Risk is negative in all years except the financial crisis period when market volatility was abnormally high. Before SOX, the completion of an acquisition results in a mean increase in stock return volatility of $12.1 \%$ while in the post-SOX period the mean increase is only $4.9 \%$. The $D \_R i s k \_A b R$ variable shows an even larger difference between pre- and post-SOX risk-taking and all differences are significant at the $1 \%$ level.

The remaining columns in Table 1 show a notable shift in the structure of incentive compensation over time, which is consistent with the documented decrease in the use of stock options following the passage of SOX and SFAS No. 123R (Chang et al. 2012; Dicks 2012; Tang 2014). New grants of executive stock options fall after the passage of the Act (a significant at the 1\% level change). While stock options account, on average, for $37.4 \%$ of the top five executives' compensation before 2002, this falls to $31.1 \%$ post-SOX. At the same time, we observe a substantial increase in the use of restricted stock with its mean value to total compensation rising from $4.3 \%$ before SOX to $16.1 \%$ post-SOX. As a result, the total value of equity-based compensation as a percentage of total compensation increases post-SOX, driven by the increase in restricted stock.

This preliminary evidence suggests that the structure of executive compensation changed significantly post-SOX. Subsequently, this can affect managerial incentives to take risk given that restricted stock is less effective than options in mitigating risk-aversion (Smith and Watts 1982; Guay 1999). The change in compensation structure is also consistent with corporate incentives to avoid excessive risk exposure post-SOX (Flor et al. 2014). Although the average sensitivity of managerial wealth to stock price performance (Delta) was equal across the two periods, the sensitivity of managerial wealth to stock return 


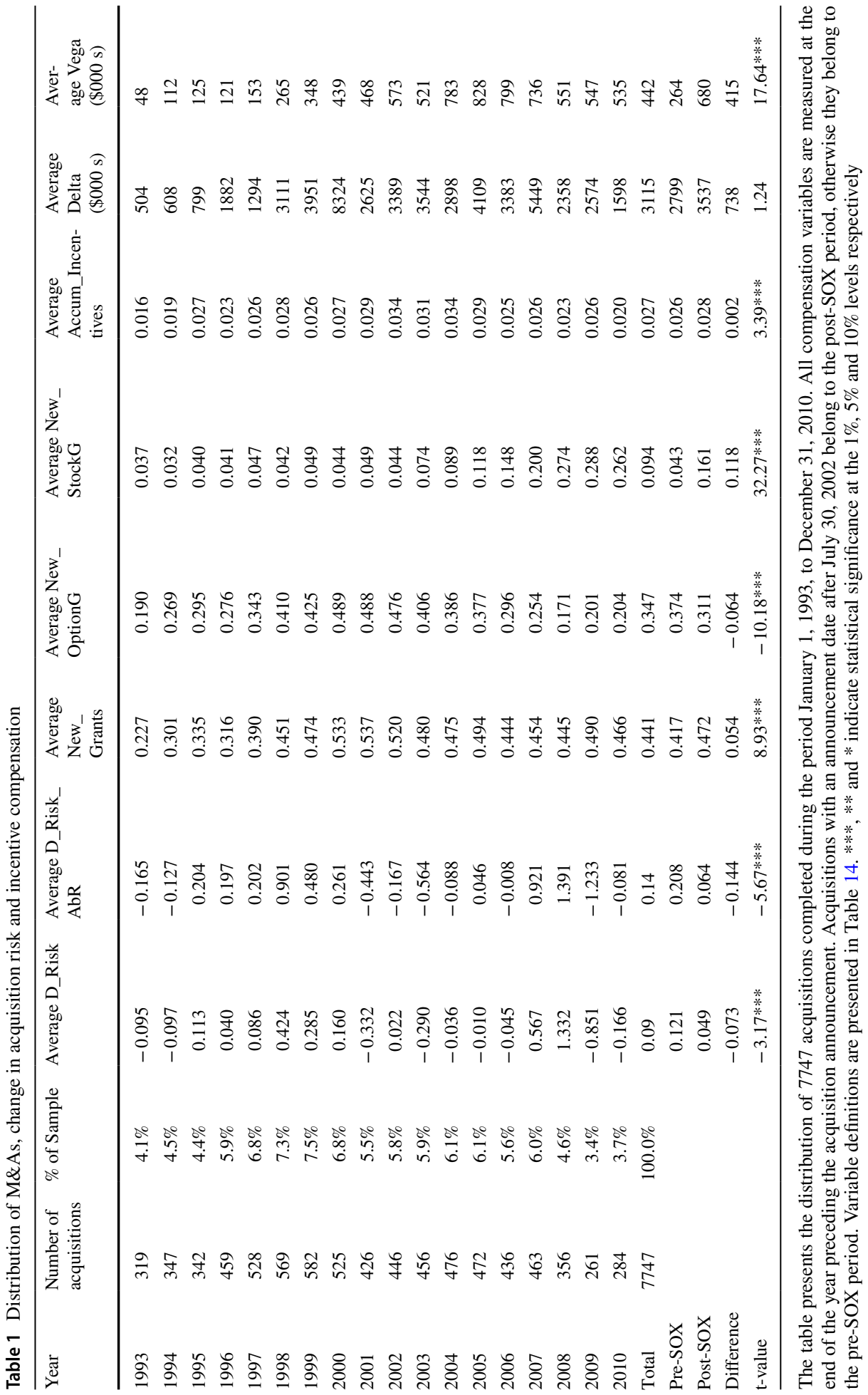


volatility (Vega) jumped in the period after SOX. The average value of Vega increases from $\$ 264,000$ in the pre-SOX period to $\$ 680,000$ post-SOX and the change is significant at the $1 \%$ level.

We expect the increase in pay-risk sensitivity to be associated with stronger incentives for risky acquisitions, all else equal. However, since managers appear to perceive equity incentives differently post-SOX as we show in this paper, compensation committees may have raised pay-risk sensitivity to avoid undesired risk-aversion following the enactment of SOX.

\subsection{Control variables}

We control for the payment method using the dummy variables Payment_Cash and Payment_Stock. These are set equal to one if the deal is financed by only cash or equity respectively, and zero otherwise. Prior research has shown that bidders who have insufficient information about the target are more likely to finance the transaction with stock (Hansen 1987; Officer 2007) to mitigate information asymmetry problems. Given that cash financing is associated with lower information asymmetry, we expect it to result in lower stock return volatility following the transaction. We define Size as the natural logarithm of the bidder's market capitalization four weeks prior to the acquisition announcement date. Bargeron et al. (2010) document a larger fall in the standard deviation of stock returns for small firms relative to large firms following SOX. Sales_Growth is the natural logarithm of the ratio of bidder's sales in the year preceding the acquisition announcement $(\mathrm{t}-1)$ to sales in the previous year $(t-2)$. Since risk-taking incentives are positively related to the firm's investment opportunities (Guay 1999; Benson et al. 2019) we expect a positive relation between sales growth and firm risk. Cash/Assets is the ratio of cash and cash equivalents to total assets. Yermack (1995) and Dechow et al. (1996) note that liquidityconstrained firms are more likely to use stock options in executive compensation packages. $R O A$ is the bidder's operating income before depreciation divided by total assets.

We include leverage to ensure any observed change in firm risk is not due to changes in capital structure. D_Leverage is the change in the ratio of total debt to total assets from the year-end preceding the acquisition announcement to the subsequent year. ${ }^{6}$ While riskaverse managers prefer to avoid debt (Berger et al. 1997), we expect that managers of highly leveraged firms have fewer incentives to further increase risk (John and John 1993). $R \& D$ is the bidder's research and development expenditure to total assets and we treat missing R\&D values as zero. ${ }^{7}$ Investment in R\&D can increase with risk-taking incentives (Nam et al. 2003; Coles et al. 2006), but Bargeron et al. (2010) find that more specialized firms with higher investment in R\&D before SOX significantly reduced their risk-taking activity post-SOX relative to firms with low R\&D. Net_PPE is the acquirer's net property, plant and equipment to total assets. Since this is typically a less-risky investment, we expect a negative relation between Net PPE and pay-risk sensitivity.

We also control for a range of corporate governance characteristics that may substitute or compliment executive compensation in motivating managers to undertake risky investments. We control for CEO tenure and predict that entrenchment increases with tenure,

\footnotetext{
${ }^{6}$ We use the book value of leverage to avoid any changes in the market value of leverage that could be due to changes in stock price rather than from deliberate managerial choices (Welch 2004).

7 Our results are unaffected if we exclude observations where R\&D data is missing.
} 
leading to decisions characterized by higher risk-aversion. Tenure is the number of months the CEO has served in office at the time of the acquisition announcement. In addition, Banerjee et al. $(2015,2018)$ show that the reduction in risk-taking activity post-SOX can be explained by restrained CEO overconfidence. We control for the impact of this factor on our results using the variable Overconfidence which, following Banerjee et al. (2015), is defined as the value per in-the-money vested option retained by the CEO scaled by the stock price of the firm at the end of the fiscal year. The value per in-the-money vested option is calculated as the value of all unexercised vested options retained by the CEO divided by the total number of these options. For a sub-sample of firms with available data in BoardEx we examine the proportion of independent directors on the board, Indep Directors, as well as the proportion of independent directors in the audit committee, Audit_ Indep, given the mandate of SOX for audit committee independence (Linck et al. 2009). CEO/Chairman is a dummy variable set equal to one if the CEO is also the Chairman, and zero otherwise. Among other provisions, the Sarbanes-Oxley Act established a number of rules and restrictions with regard to board structure, including the requirement for independent boards, to improve the quality of corporate governance. Dicks (2012) shows that governance regulation is a substitute for incentive pay as an agency-cost mitigating mechanism whereby the passage of SOX led to a decrease in incentive compensation. Along the same lines, Chhaochharia and Grinstein (2009) find that firms who had to implement structural changes in their boards following the passage of the Act lowered equity-based compensation. Therefore, changes in board structure post-SOX can have an important impact on managerial equity-based incentives and their subsequent effect on decision-making.

Table 2 presents summary statistics for our sample variables. The mean and median value of new equity grants is close to $45 \%$ of total pay, with stock options dominating this percentage mainly due to their use in the pre-SOX period as shown in Table 1 . The median value of both new stock grants and unvested stock is zero since the majority of acquirers do not pay restricted stock to their executives until after SOX. Mean and median values of Delta and Vega are higher than those in previous studies (Coles et al. 2006; Cohen et al. 2013) as we examine the sensitivity of top five executives' wealth to stock price performance and volatility, rather than solely that of the CEO. ${ }^{8}$

Summary statistics for control variables are generally in line with prior studies (Cohen et al. 2013; Croci and Petmezas 2015). The average acquiring firm is large, with market capitalization of approximately $\$ 2.8 \mathrm{bn}$, reflecting the focus on S\&P1500 firms in ExecuComp. The acquiring firms in our sample are generally profitable and have positive investment opportunities based on sales growth, $R \& D$ and capital expenditures. Median CEO tenure is 5.67 years and for $62.3 \%$ of the firms in our sample the CEO also serves as Chairman. The overconfidence of acquiring CEOs has a mean and median value of 0.40 and 0.38 respectively, comparable to those reported by Banerjee et al. (2015) for their M\&A sub-sample. $82.5 \%(85.7 \%)$ of the average (median) firm's board members are independent directors while the mean (median) proportion of audit committee independence is $93.5 \%$ $(100 \%)$. This makes sense given that this variable is mainly available for the post-SOX period in our sample ${ }^{9}$ during which SOX requires audit committees to consist entirely of independent directors (Linck et al. 2009). Regarding the method of payment, almost half

\footnotetext{
${ }^{8}$ Coles et al. (2006) report compensation data for the management team excluding the CEO and so the reported dollar values of Delta and Vega are significantly lower than those reported here. Moreover, our dollar values are expressed in 2010 USD which is also different than the base year in Coles et al. (2006).

9 Data for the estimation of board and audit committee independence is available since 1999 in BoardEx.
} 
of the deals are financed only with cash with $19 \%$ being financed only with equity and the remaining $30 \%$ with a mixed method of financing. ${ }^{10}$

\subsection{Univariate analysis of changes in acquisition risk}

Table 3 presents differences in the change in firm risk surrounding the acquisition effective date between the pre- and post-SOX periods by selected incentive compensation measures. We classify firms with incentive compensation higher than the sample median for each variable as High Incentive firms (HI); otherwise, we classify them as Low Incentive firms $(L I) .{ }^{11}$ Panels $\mathrm{A}$ and $\mathrm{B}$ examine the change in bidder risk for $H I$ and $L I$ acquirers respectively. Panel B also presents tests of differences in stock return volatility before and after SOX between the $H I$ and $L I$ sub-samples.

The findings are striking. Before SOX, $H I$ firms make acquisition decisions that increase the volatility of their stock returns, consistent with the view that incentive pay makes acquiring managers less risk-averse (Datta et al. 2001). However, in the post-SOX period, the same firms make less risky acquisitions, and the drop from pre- to post-SOX is statistically significant at the $1 \%$ level across all measures of incentive compensation. Focusing on New_Grants, the value of -0.157 in Panel B is significant at the $1 \%$ level and shows that the decrease in acquisition risk after SOX is significantly greater for higher incentivized managers relative to their lower incentivized counterparts.

These findings are robust to alternative incentive compensation measures. For instance, the average decrease in stock return volatility between pre- and post-SOX is $12.0 \%$ larger for HI bidders when Accum_Incentives is used as the compensation variable, (significant at the $1 \%$ level). Focusing on pay-risk sensitivity (Vega), the decrease in risk is again greater for $\mathrm{HI}$ firms by $10.7 \%$ with the difference being significant at the $5 \%$ level. On the other hand, we find no statistically significant change in risk when acquiring firms are grouped by the level of pay-performance sensitivity (Delta), which largely reflects managerial incentives stemming from their stock holdings in the company (Core and Guay 2002; Coles et al. 2006). These results provide preliminary empirical support to our predictions that acquiring managers respond differently to equity incentives post-SOX with the impact on risk-taking being driven by their option portfolio.

\subsection{Multivariate analysis of acquisition risk and incentive compensation}

Table 4 extends our work to a multivariate setting. In addition to standard deal, firm, and governance variables, we control for confounding events, including the collapse of technology stocks in 2000/2001, the passage of SFAS No.123R in 2005/2006, and the global financial crisis in 2008. All multivariate models include industry fixed effects

\footnotetext{
10 This pattern is similar to those provided by other studies (e.g. Loughran and Vijh 1997; Draper and Paudyal 2006; Bi and Gregory 2011; Croci and Petmezas 2015) subject to sample selection characteristics. For instance, Bi and Gregory (2011) report that $48 \%$ of the large firms in their sample use cash as a method of financing. Our sample, due to the ExecuComp criterion, consists of mainly large firms. Croci and Petmezas (2015) who also use an ExecuComp-matched sample, show that $46 \%$ of the transactions in their sample are financed only with cash while $19 \%$ of the deals are financed only with equity.

11 Given the notable changes in compensation over the sample period documented in Table 1, we re-estimate this analysis and classify observations as $H I$ and $L I$ according to annual values for incentive compensation. The results are unchanged using this alternative classification.
} 
Table 2 Summary statistics

\begin{tabular}{|c|c|c|c|c|c|c|}
\hline Variable & Mean & Standard deviation & 25th Percentile & Median & 75th Percentile & $\begin{array}{l}\text { Number of } \\
\text { observa- } \\
\text { tions }\end{array}$ \\
\hline
\end{tabular}

Risk Measures

D Risk

$0.089 \quad 0.988$

$-0.389$

$0.006 \quad 0.458$

7747

D_Risk_AbR

$0.144 \quad 1.096$

$-0.378$

$0.052 \quad 0.580$

7675

Compensation Variables

New_Grants
New_OptionG
New_StockG
Unex_Options
Unvest_Stock
Accum_Incentives
Delta (\$000 s)
Vega (\$000 s)
Cash_Comp
(\$000 s)
Firm Character-
istics

\begin{tabular}{lclllll} 
Size & 14.885 & 1.648 & 13.670 & 14.670 & 15.910 & 7747 \\
Cash/Assets & 0.155 & 0.179 & 0.026 & 0.076 & 0.225 & 7709 \\
ROA & 0.132 & 0.105 & 0.065 & 0.132 & 0.191 & 7742 \\
Sales_Growth & 0.065 & 0.123 & 0.005 & 0.045 & 0.106 & 7599 \\
D_Leverage & 0.015 & 0.091 & -0.021 & 0.000 & 0.039 & 7701 \\
R\&D & 0.035 & 0.063 & 0.000 & 0.000 & 0.050 & 7747 \\
Net_PPE & 0.206 & 0.219 & 0.045 & 0.133 & 0.284 & 7672 \\
CAPEX & 0.046 & 0.058 & 0.010 & 0.030 & 0.060 & 7.672 \\
Tenure & 100 & 126 & 32 & 68 & 126 & 7148 \\
Overconfidence & 0.400 & 0.390 & 0.138 & 0.380 & 0.598 & 7005 \\
Payment_Cash & 0.514 & 0.500 & 0 & 1 & 1 & 7747 \\
Payment_Stock & 0.189 & 0.392 & 0 & 0 & 0 & 7747 \\
CEO/Chairman & 0.623 & 0.485 & 0 & 1 & 1 & 6685 \\
Indep_Directors & 0.825 & 0.0958 & 0.778 & 0.857 & 0.889 & 3915 \\
Audit_Indep & 0.935 & 0.1498 & 1.000 & 1.000 & 1.000 & 3928 \\
\hline
\end{tabular}

The table presents summary statistics for the sample of 7747 acquisitions completed during the period January 1,1993 , to December 31,2010 . Data on executive compensation are from ExecuComp, stock price data from CRSP and accounting data from Compustat. Unless otherwise specified, all variables are measured at the end of the year preceding the acquisition announcement. Variable definitions are presented in Table 14

based on the Fama and French (1997) 48-industry classification approach. This controls for residual cross-sectional differences in costs of compliance with the Act and compensation incentives (see Chhaochharia and Grinstein 2009; Leuz and Wysocki 2016). 
Table 3 Change in standard deviation of acquirer's stock returns around the effective date

\begin{tabular}{llll}
\hline Compensation variable & Pre-SOX & Post-SOX & $\begin{array}{l}\text { Difference post } \\
\text { vs pre }\end{array}$ \\
\hline
\end{tabular}

Panel A: high executive incentives

New_Grants

Median

Observations

Accum_Incentives

Mean

Observations

Delta

$\begin{array}{ll}\text { Mean } & 0.150 \\ \text { Median } & 0.055 \\ \text { Observations } & 1933\end{array}$

Vega

$\begin{array}{ll}\text { Mean } & 0.148 \\ \text { Median } & 0.043\end{array}$

Observations

1681

Panel B: low executive incentives

New_Grants

Mean

Observations

High VS low incentives

Accum_Incentives

Mean

Observations

High VS low incentives

Delta

Mean

Observations

0.076

0.030

2412

High VS low incentives

Vega

$\begin{array}{ll}\text { Mean } & 0.104 \\ \text { Median } & 0.032 \\ \text { Observations } & 2609\end{array}$

High VS low incentives

0.177
0.046
1948

148

0.098

0.035

2350

0.098

0.028

2357
Mean

0.024
-0.049
1925

0.017

$-0.041$

1871

0.063

$-0.028$

1812

0.025

$-0.040$

$-0.123$

$-0.131$

$-0.074$

$-3.96^{* * * *}$

$-3.81 * * *$

2064

The table presents changes in the standard deviation of stock returns of the acquiring firms around the acquisition effective date. The sample is 7747 completed U.S. acquisitions over the period January 1, 1993, to December 31, 2010 from SDC Platinum. Acquisitions with an announcement date after July 30, 2002 belong to the post-SOX period, otherwise they belong to the pre-SOX period. Data on executive compensation are from ExecuComp and stock price data from CRSP. Variable definitions are presented in Table 14. t-statistics are from the t-test of difference between means and $z$-statistics are from the Wilcoxon rank sum test for difference between the respective medians. $* * *, * *$ and $*$ indicate statistical significance at the $1 \%$, $5 \%$ and $10 \%$ levels respectively 
Table 4 Multivariate analysis of change in acquisition risk on new incentive grants

\begin{tabular}{|c|c|c|c|}
\hline Variable & D_Risk Model 1 & D_Risk Model 2 & D_Risk Model 3 \\
\hline Intercept & $\begin{array}{l}-0.4354 * * \\
(-2.05)\end{array}$ & $\begin{array}{l}-0.3778^{*} \\
(-1.77)\end{array}$ & $\begin{array}{l}-0.3187 \\
(-1.50)\end{array}$ \\
\hline New_Grants & $\begin{array}{l}0.2638^{* * * *} \\
(3.66)\end{array}$ & & \\
\hline New_Grants*SOX & $\begin{array}{l}-0.5412 * * * \\
(-5.48)\end{array}$ & & \\
\hline New_OptionG & & $\begin{array}{l}0.2499 * * * \\
(3.47)\end{array}$ & \\
\hline New_OptionG*SOX & & $\begin{array}{l}-0.4766^{* * *} \\
(-5.16)\end{array}$ & \\
\hline New_StockG & & & $\begin{array}{l}0.0766 \\
(0.58)\end{array}$ \\
\hline New_StockG*SOX & & & $\begin{array}{l}-0.1115 \\
(-0.67)\end{array}$ \\
\hline SOX & $\begin{array}{l}-0.0114 \\
(-0.23)\end{array}$ & $\begin{array}{l}-0.0776^{* *} \\
(-1.97)\end{array}$ & $\begin{array}{l}-0.2422^{* * *} \\
(-8.13)\end{array}$ \\
\hline Cash_Comp & $\begin{array}{l}0.0013 \\
(0.50)\end{array}$ & $\begin{array}{l}0.0018 \\
(0.68)\end{array}$ & $\begin{array}{l}0.0012 \\
(0.46)\end{array}$ \\
\hline Internet_Crash & $\begin{array}{l}-0.0319 * * * \\
(-3.88)\end{array}$ & $\begin{array}{l}-0.0312^{* * * *} \\
(-3.81)\end{array}$ & $\begin{array}{l}-0.0252^{* * * *} \\
(-3.18)\end{array}$ \\
\hline SFAS_123R & $\begin{array}{l}0.0588 \\
(1.64)\end{array}$ & $\begin{array}{l}0.0558 \\
(1.54)\end{array}$ & $\begin{array}{l}0.0723^{* *} \\
(2.00)\end{array}$ \\
\hline Financial_Crisis & $\begin{array}{l}0.1083^{* * *} \\
(10.61)\end{array}$ & $\begin{array}{l}0.1044 * * * \\
(10.12)\end{array}$ & $\begin{array}{l}0.1096 \text { *** } \\
(10.76)\end{array}$ \\
\hline Size & $\begin{array}{l}0.0411^{* * *} \\
(4.30)\end{array}$ & $\begin{array}{l}0.0386^{* * * *} \\
(4.05)\end{array}$ & $\begin{array}{l}0.0405^{* * * *} \\
(4.38)\end{array}$ \\
\hline D_Leverage & $\begin{array}{l}0.4036^{* * *} \\
(2.73)\end{array}$ & $\begin{array}{l}0.4008 * * * \\
(2.71)\end{array}$ & $\begin{array}{l}0.3857 \text { *** } \\
(2.61)\end{array}$ \\
\hline Sales_Growth & $\begin{array}{l}0.2771 * * \\
(2.18)\end{array}$ & $\begin{array}{l}0.2744 * * \\
(2.14)\end{array}$ & $\begin{array}{l}0.3201 * * \\
(2.54)\end{array}$ \\
\hline Payment_Cash & $\begin{array}{l}-0.1048 * * * \\
(-3.86)\end{array}$ & $\begin{array}{l}-0.1048^{* * * *} \\
(-3.85)\end{array}$ & $\begin{array}{l}-0.1062 * * * \\
(-3.90)\end{array}$ \\
\hline Payment_Stock & $\begin{array}{l}-0.0109 \\
(-0.26)\end{array}$ & $\begin{array}{l}-0.0087 \\
(-0.21)\end{array}$ & $\begin{array}{l}-0.0040 \\
(-0.10)\end{array}$ \\
\hline Tenure & $\begin{array}{l}-0.0033 \\
(-0.35)\end{array}$ & $\begin{array}{l}-0.0033 \\
(-0.35)\end{array}$ & $\begin{array}{l}-0.0063 \\
(-0.66)\end{array}$ \\
\hline Overconfidence & $\begin{array}{l}-0.0414 \\
(-1.28)\end{array}$ & $\begin{array}{l}-0.0387 \\
(-1.21)\end{array}$ & $\begin{array}{l}-0.0266 \\
(-0.87)\end{array}$ \\
\hline Number of observations & 6434 & 6434 & 6434 \\
\hline F-statistic & $6.09 * * *$ & $9.89 * * *$ & $6.08 * * *$ \\
\hline R-squared & 0.078 & 0.077 & 0.073 \\
\hline Industry fixed effects & YES & YES & YES \\
\hline
\end{tabular}

The table presents multivariate analysis of the change in risk of acquiring firms included in the sample of 7747 acquisitions completed during the period January 1, 1993, to December 31, 2010 from SDC Platinum. Variable definitions are presented in Table 14. t-statistics based on robust standard errors are in parenthesis. $* * *, * *$ and $*$ indicate statistical significance at the $1 \%, 5 \%$ and $10 \%$ levels respectively 
Consistent with previous research findings (Datta et al. 2001), Model 1 shows that incentive compensation in the pre-SOX period induces managers to make risk-increasing acquisitions. The coefficient of New_Grants is positive and significant at the $1 \%$ level. However, the interaction coefficient of New_Grants*SOX is significantly negative, showing that the impact of new incentive grants on the riskiness of acquisition decisions has changed post-SOX. Managers appear to evaluate risk-taking incentives provided by equityrelated compensation in a more conservative way in the new regulatory environment. The results are also economically important indicating that the positive impact of new equity grants on risk-taking activity is more than offset by the effects of SOX. Before SOX, one standard deviation increase in New_Grants increases the standard deviation of stock returns by $7 \%$ following the completion of a deal, a $79 \%$ increase relative to the average $D \_$Risk. However, post-SOX a similar increase in New_Grants is associated with a 7.4\% decrease in the riskiness of corporate takeovers [i.e., $0.2665 \times(0.2638-0.5412)]$, an $83 \%$ decrease relative to its mean.

We extend this analysis in Models 2 and 3 to differentiate between the impact of new stock options and restricted stock grants on risk-taking. Our descriptive statistics show an increased use of restricted stock grants in the post-SOX period. Theories of executive compensation predict that a switch away from options will lead to a decline in risk-seeking behavior by firms (Nohel and Todd 2005; Coles et al. 2006). Consistent with Guay (1999) and Parrino et al. (2005), for the pre-SOX period the coefficient of New_OptionG is positive and significant at the $1 \%$ level, while New_StockG is unrelated to changes in risk. This reflects the convex payoff function inherent in executive stock options and confirms our prediction that the change in the way executives react to equity incentives post-SOX stems from their option portfolio. In accordance with this conjecture, our results confirm that almost the entire economic effect of equity grants on risk-taking is captured by stock options. Before SOX, one standard deviation increase in new option grants (New_OptionG) increases $D \_$Risk by $6.9 \%$ (a $77 \%$ increase relative to its mean) while post-SOX a similar increase in New_OptionG reduces $D \_R i s k$ by $6.2 \%$ (a $70 \%$ increase relative to its mean).

The signs of the control variables are as expected. Risk taking decreases post-SOX (Bargeron et al. 2010) and we observe a higher post-acquisition volatility of stock returns for poor performing acquirers that initiated corporate takeovers during the financial crisis. Large firms have a higher capacity for risk taking which is also positively related to sales

growth (Guay 1999). By definition, the volatility of stock returns increases with leverage while the use of cash as payment method is associated with lower uncertainty regarding the quality of the deal (Officer 2007).

\subsubsection{Sensitivity analysis: corporate governance}

In this section, we extend our baseline OLS results to examine the robustness of our findings to inclusion of corporate governance characteristics. Linck et al. (2009) show an increase in board independence following the introduction of SOX. The Act simultaneously increased demand for independent directors by mandating greater use while at the same time reducing their supply by increasing workload and making independent directors subject to greater personal liabilities. Coles et al. (2014) note similar findings for their sample of co-opted directors. Dicks (2012) posits that corporate governance is a substitute for incentive compensation, while Jiménez-Angueira and Stuart (2015) find that effective corporate governance systems lead firms to set incentive compensation optimally with respect to firm performance. 
Therefore, a concern with our baseline findings is that M\&A decisions are not solely driven by compensation incentives, and any changes in the quality of governance following the SOX may contaminate our results. Under this explanation, the weak post-SOX remuneration incentives - risk-taking relationship may be the result of board characteristics that hamper managerial risk-taking and are omitted from the analysis. In other words, it is not that managers became less responsive to incentives, but they are stopped from taking particular forms of risk by active board monitoring.

To address this concern, we re-estimate our baseline results including controls for board governance and their interaction with SOX. We include the proportion of independent directors on the board, Indep_Directors, the proportion of independent directors on the audit committee, Audit_Indep, the dummy variable CEO/Chairman to control for CEO duality and our measure for CEO Overconfidence. We include interactions of all these governance measures with the SOX dummy to control for their impact on risk-taking following the passage of the Act. If the negative relation between option-based incentives and risktaking post-SOX documented in our earlier tests is driven by the impact of other governance factors, the inclusion of these variables in the analysis should remove the significant compensation effect in our baseline findings.

We present these results in Table 5. Board independence appears to reduce risk-taking before SOX (significant at the 10\% level in Models 1 and 2) but it does not have a material impact post-SOX. Surprisingly, audit committee independence is positively associated with risk-taking post SOX, but controlling for this relation does not affect our baseline findings. Furthermore, CEO overconfidence does not appear to explain the shift in risktaking activity post-SOX.

Including these variables does not affect the impact of incentive compensation on postacquisition changes in firm risk surrounding SOX. Both the interaction of New_Grants (Model 1) and New_OptionsG (Model 2) with SOX remain negative and retain their statistical significance at the $1 \%$ level. Our results suggest that changes in board independence and CEO overconfidence surrounding the passage of the Act do not affect the relation between executive compensation and managerial incentives to undertake risky corporate investments. Because governance data from BoardEx is available only for a sub-set of our main sample resulting in a substantial drop in observations ${ }^{12}$ we exclude these governance controls from the remainder of our analysis. ${ }^{13}$

\footnotetext{
12 Governance data is available in BoardEx only since 1999.

13 Inclusion of these additional controls for board governance (CEO/Chairman, Indep_Directors and Audit_Indep) does not affect the results presented subsequently in this paper when we use alternative incentive compensation measures. Results are available in Online Appendix Table 5c. We also use the governance index (GIM index) of Gompers et al. (2003) to capture changes in corporate governance quality between the pre- and post-SOX period that could have affected our results. The use of a broader governance index further controls for a potential correlation between the various corporate governance proxies used earlier in the analysis. Our results remain unchanged and are available in Tables 5e and $6 \mathrm{e}$ of the Online Appendix. In further robustness checks, we supplement the GIM index with director ownership, since Bhagat and Bolton (2008) show that a composite measure of corporate governance combining both GIM index and director ownership is a more powerful predictor of operating performance than either measure by itself. Our results remain unchanged and are available in Tables $5 \mathrm{f}$ and $6 \mathrm{f}$ of the Online Appendix. In final tests, we construct an internal governance index which we incorporate into the analysis along with the GIM index to capture more effectively the impact of both external and internal governance factors surrounding the passage of SOX. Our results remain unaffected, are available in Tables $5 \mathrm{~g}$ and $6 \mathrm{~g}$ of the Online Appendix and are robust to controls for endogeneity [following Bebchuk et al. (2009) and using five-year lagged internal governance index data. Online Appendix tables: 5 h-6i].
} 


\subsubsection{Sensitivity analysis: accumulated incentive compensation}

Restricting our analysis to new stock and option grants may not be representative of managerial incentives at the point in time when investment decisions are made. Accumulated incentives can be equally important given that newly granted incentives cannot be exercised immediately. Table 6 repeats the analysis by looking at the impact of accumulated incentives on changes in firm risk surrounding acquisitions.

In Model 1 the coefficient of Accum_Incentives is positive and significant at the $1 \%$ level confirming that equity incentives granted in previous years have an important impact on managerial behavior before SOX. However, similar to our findings about new equity grants, the interaction coefficient of Accum_Incentives*SOX is negative and significant at the $1 \%$ level, revealing an important weakening in the positive effect that accumulated incentives have on acquisition risk post-SOX.

Models 2 and 3 separate accumulated incentives into unexercised options and unvested stock respectively. Confirming our earlier analysis, the results show that stock options mitigate managerial risk-aversion more effectively than restricted stock before SOX. The coefficient of Unex_Options is positive and significant at the 1\% level while that of Unvest_Stock is positive but statistically insignificant. Models 2 and 3 also confirm that the weakening in the relation between equity incentives and risk-taking post-SOX is driven by the executives' option portfolio. The coefficient of Unex_Options*SOX is negative and significant at the $1 \%$ level while that of Unvest_Stock*SOX is statistically insignificant. Economically, the impact of accumulated incentives on risk-taking is important but less than the impact of new equity grants. For instance, one standard deviation increase in Unex_Options increases D_Risk by $8.4 \%$ before SOX but only by $0.4 \%$ post-SOX showing an important weakening in the relationship between option grants and risk-taking. However, Model 2 in Table 4 shows that a one standard deviation increase in new option grants post-SOX reduces $D_{-}$ Risk by $6.2 \%$, changing the way managers respond to equity incentives.

In Models 4 and 5, we extend our analysis of accumulated incentives to examine the role of pay-performance (Delta) and pay-risk (Vega) sensitivity ${ }^{14}$ on risk taking. Coles et al. (2006) show that while Vega is associated with riskier investments and higher stock return volatility, the impact of Delta on firm risk is not so clear. A higher Delta increases the sensitivity of managers' wealth to changes in firm value and can lead either to riskier investments (John and John 1993) or increased risk aversion (Guay 1999). Model 4 shows that Delta cannot explain post-acquisition changes in firm risk. In contrast, Model 5 shows that the change in the way managers perceive risk-taking incentives post-SOX can be captured by the pay-risk sensitivity of their option portfolio. Before SOX, an increase by one standard deviation in Vega increases $D \_R i s k$ by $4 \%$ but post-SOX a similar increase in Vega decreases $D \_R i s k$ by $1 \%$. The difference is statistically significant at the $10 \%$ level and economically important too as it represents a change of $57 \%$ relative to the mean of the dependent variable.

\footnotetext{
${ }^{14}$ In line with previous studies (i.e. Coles et al. 2006), Delta and Vega are entered in millions of dollars in the multivariate regressions.
} 
Table 5 Change in acquisition risk on new incentive grants with additional controls for corporate governance

\begin{tabular}{|c|c|c|c|}
\hline Variable & D_Risk Model 1 & D_Risk Model 2 & D_Risk Model 3 \\
\hline \multirow[t]{2}{*}{ Intercept } & -0.1030 & 0.0342 & 0.1042 \\
\hline & $(-0.22)$ & $(0.07)$ & $(0.23)$ \\
\hline \multirow[t]{2}{*}{ New_Grants } & $0.3120^{*}$ & & \\
\hline & $(1.79)$ & & \\
\hline \multirow[t]{2}{*}{ New_Grants*SOX } & $-0.5924 * * *$ & & \\
\hline & $(-3.23)$ & & \\
\hline \multirow[t]{2}{*}{ New_OptionG } & & $0.2808 *$ & \\
\hline & & $(1.70)$ & \\
\hline \multirow[t]{2}{*}{ New_OptionG*SOX } & & $-0.4537 * * *$ & \\
\hline & & $(-2.67)$ & \\
\hline \multirow[t]{2}{*}{ New_StockG } & & & 0.0996 \\
\hline & & & $(0.31)$ \\
\hline \multirow[t]{2}{*}{ New_StockG*SOX } & & & -0.2179 \\
\hline & & & $(-0.64)$ \\
\hline \multirow[t]{2}{*}{ SOX } & $-1.2085 * * *$ & $-1.2748 * * *$ & $-1.4684 * * *$ \\
\hline & $(-2.70)$ & $(-2.86)$ & $(-3.34)$ \\
\hline \multirow[t]{2}{*}{ Cash_Comp } & -0.0002 & 0.0004 & 0.0001 \\
\hline & $(-0.07)$ & $(0.14)$ & $(0.03)$ \\
\hline \multirow[t]{2}{*}{ Internet_Crash } & $-0.0431 * * *$ & $-0.0420 * * *$ & $-0.0366^{* * *}$ \\
\hline & $(-3.31)$ & $(-3.26)$ & $(-2.90)$ \\
\hline \multirow[t]{2}{*}{ SFAS_123R } & 0.0394 & 0.0415 & 0.0532 \\
\hline & $(1.01)$ & $(1.05)$ & $(1.36)$ \\
\hline \multirow[t]{2}{*}{ Financial_Crisis } & $0.1000^{* * *} *$ & $0.0974 * * *$ & $0.1027 * * *$ \\
\hline & $(8.95)$ & $(8.58)$ & $(9.21)$ \\
\hline \multirow[t]{2}{*}{ Size } & $0.0537 * * *$ & $0.0473 * * *$ & $0.0462 * * *$ \\
\hline & $(4.03)$ & $(3.55)$ & $(3.59)$ \\
\hline \multirow[t]{2}{*}{ D_Leverage } & 0.3537 & 0.3530 & 0.3230 \\
\hline & $(1.63)$ & $(1.63)$ & $(1.49)$ \\
\hline \multirow[t]{2}{*}{ Sales_Growth } & 0.2749 & 0.2691 & 0.2710 \\
\hline & $(1.42)$ & $(1.39)$ & $(1.42)$ \\
\hline \multirow[t]{2}{*}{ Payment_Cash } & -0.0403 & -0.0409 & -0.0417 \\
\hline & $(-1.06)$ & $(-1.07)$ & $(-1.09)$ \\
\hline \multirow[t]{2}{*}{ Payment_Stock } & 0.0279 & 0.0364 & 0.0434 \\
\hline & $(0.33)$ & $(0.44)$ & $(0.52)$ \\
\hline \multirow[t]{2}{*}{ Tenure } & -0.0276 & -0.0267 & -0.0267 \\
\hline & $(-1.53)$ & $(-1.47)$ & $(-1.46)$ \\
\hline \multirow[t]{2}{*}{ CEO/Chairman } & -0.0240 & -0.0283 & -0.0585 \\
\hline & $(-0.30)$ & $(-0.36)$ & $(-0.74)$ \\
\hline \multirow[t]{2}{*}{ CEO/Chairman*SOX } & 0.0743 & 0.0768 & 0.1123 \\
\hline & $(0.84)$ & $(0.87)$ & $(1.28)$ \\
\hline \multirow[t]{2}{*}{ Indep_Directors } & $-0.6935^{*}$ & $-0.6805^{*}$ & -0.5952 \\
\hline & $(-1.94)$ & $(-1.90)$ & $(-1.64)$ \\
\hline \multirow[t]{2}{*}{ Indep_Directors*SOX } & 0.4339 & 0.3904 & 0.3597 \\
\hline & $(1.05)$ & $(0.94)$ & $(0.86)$ \\
\hline
\end{tabular}


Table 5 (continued)

\begin{tabular}{llll}
\hline Variable & D_Risk Model 1 & D_Risk Model 2 & D_Risk Model 3 \\
\hline Audit_Indep & -0.2320 & -0.2393 & -0.2350 \\
& $(-1.28)$ & $(-1.32)$ & $(-1.29)$ \\
Audit_Indep*SOX & $0.8814^{* * *}$ & $0.8793 * * *$ & $0.9297 * * *$ \\
& $(3.21)$ & $(3.21)$ & $(3.35)$ \\
Overconfidence & -0.0879 & -0.0881 & -0.0587 \\
& $(-0.94)$ & $(-0.94)$ & $(-0.70)$ \\
Overconfidence*SOX & 0.0629 & 0.0707 & 0.0211 \\
& $(0.48)$ & $(0.54)$ & $(0.17)$ \\
Number of observations & 3277 & 3277 & 3277 \\
F-statistic & $4.84 * * *$ & $3.80^{* * *}$ & $3.75^{* * *}$ \\
R-squared & 0.111 & 0.109 & 0.107 \\
Industry fixed effects & YES & YES & YES \\
\hline
\end{tabular}

The table presents multivariate analysis of the change in risk of acquiring firms included in the sample of 7747 acquisitions completed during the period January 1, 1993, to December 31, 2010 from SDC Platinum. Variable definitions are presented in Table 14. t-statistics based on robust standard errors are in parenthesis. $* * *, * *$ and $*$ indicate statistical significance at the $1 \%, 5 \%$ and $10 \%$ levels respectively

\subsection{Summary}

Executive compensation plays an important role in mitigating managerial risk aversion in the pre-SOX period, which stems from the convex nature of payoffs from executive stock options. However, the effectiveness of this mechanism in inducing risk-taking is significantly weaker post-SOX. Now, acquiring managers appear less responsive to the same risktaking incentives and perceive significantly different incentives provided by new equity grants. The change in the relation between equity incentives and risk-taking is driven by the executives' option portfolio. On the other hand, the properties of restricted stock grants, which are more closely related to the compensation characteristics captured by Delta, cannot explain changes in acquisition risk surrounding the passage of SOX.

\section{Robustness testing}

\subsection{Endogeneity tests}

Our analysis so far shows that acquiring managers have changed the way they perceive risktaking incentives post-SOX and this has led to the decreased levels of risk-taking observed in this period. However, both the decision to make risky investments and the structure of managerial compensation are likely to be endogenously determined. In other words, managers may become more risk-averse if they are provided with less risk-taking incentives but at the same time firms may adjust the structure of compensation contracts to achieve the desired level of risk-taking. Post-SOX, firms have reduced risk-taking incentives in order to control their risk-exposure (Cohen et al. 2013).

In our earlier tests, we use lagged compensation variables to avoid the impact of acquisition decisions on equity incentives. Additionally, given that we use the passage of SOX as an exogenous shock to test changes in the way managers perceive risk-taking incentives, 
Table 6 Multivariate analysis of change in acquisition risk on accumulated incentives

\begin{tabular}{|c|c|c|c|c|c|}
\hline Variable & D_Risk Model 1 & D_Risk Model 2 & D_Risk Model 3 & D_Risk Model 4 & D_Risk Model 5 \\
\hline Intercept & $\begin{array}{l}-0.5164^{* *} \\
(-2.31)\end{array}$ & $\begin{array}{l}-0.5251^{* *} \\
(-2.36)\end{array}$ & $\begin{array}{l}-0.2956 \\
(-1.38)\end{array}$ & $\begin{array}{l}-0.3268 \\
(-1.48)\end{array}$ & $\begin{array}{l}-0.3176 \\
(-1.39)\end{array}$ \\
\hline Accum_Incentives & $\begin{array}{l}2.7264^{* * * *} \\
(3.70)\end{array}$ & & & & \\
\hline $\begin{array}{l}\text { Accum_ } \\
\text { Incentives*SOX }\end{array}$ & $\begin{array}{l}-2.7780 * * * \\
(-3.18)\end{array}$ & & & & \\
\hline Unex_Options & & $\begin{array}{l}2.7953^{* * * *} \\
(3.78)\end{array}$ & & & \\
\hline $\begin{array}{l}\text { Unex__ } \\
\text { Options*SOX }\end{array}$ & & $\begin{array}{l}-2.6790 * * * \\
(-3.00)\end{array}$ & & & \\
\hline Unvest_Stock & & & $\begin{array}{l}1.7441 \\
(0.23)\end{array}$ & & \\
\hline Unvest_Stock*SOX & & & $\begin{array}{l}-5.6406 \\
(-0.72)\end{array}$ & & \\
\hline Delta & & & & $\begin{array}{l}0.0000 \\
(0.02)\end{array}$ & \\
\hline Delta*SOX & & & & $\begin{array}{l}-0.0003 \\
(-0.27)\end{array}$ & \\
\hline Vega & & & & & $\begin{array}{l}0.0421 \\
(1.29)\end{array}$ \\
\hline Vega*SOX & & & & & $\begin{array}{l}-0.0541^{*} \\
(-1.66)\end{array}$ \\
\hline SOX & $\begin{array}{l}-0.1784 * * * \\
(-5.19)\end{array}$ & $\begin{array}{l}-0.1843 \text { *** } \\
(-5.39)\end{array}$ & $\begin{array}{l}-0.2408 * * * \\
(-8.75)\end{array}$ & $\begin{array}{l}-0.2590 * * * \\
(-9.56)\end{array}$ & $\begin{array}{l}-0.2414 * * * \\
(-8.32)\end{array}$ \\
\hline Cash_Comp_Top5 & $\begin{array}{l}0.0004 \\
(0.13)\end{array}$ & $\begin{array}{l}0.0004 \\
(0.14)\end{array}$ & $\begin{array}{l}0.0013 \\
(0.48)\end{array}$ & $\begin{array}{l}0.0014 \\
(0.51)\end{array}$ & $\begin{array}{l}0.0013 \\
(0.48)\end{array}$ \\
\hline Internet_Crash & $\begin{array}{l}-0.0260 * * * \\
(-3.30)\end{array}$ & $\begin{array}{l}-0.0262 * * * \\
(-3.33)\end{array}$ & $\begin{array}{l}-0.0249^{* * *} \\
(-3.15)\end{array}$ & $\begin{array}{l}-0.0254^{* * *} \\
(-3.18)\end{array}$ & $\begin{array}{l}-0.0273^{* * *} \\
(-3.35)\end{array}$ \\
\hline SFAS_123R & $\begin{array}{l}0.0685^{*} \\
(1.90)\end{array}$ & $\begin{array}{l}0.0692 * \\
(1.92)\end{array}$ & $\begin{array}{l}0.0714 * * \\
(1.98)\end{array}$ & $\begin{array}{l}0.0746^{* *} \\
(1.98)\end{array}$ & $\begin{array}{l}0.0765^{* *} \\
(2.03)\end{array}$ \\
\hline Financial_Crisis & $\begin{array}{l}0.1086^{* * *} \\
(10.70)\end{array}$ & $\begin{array}{l}0.1087 * * * \\
(10.70)\end{array}$ & $\begin{array}{l}0.1095^{* * *} \\
(10.72)\end{array}$ & $\begin{array}{l}0.1102 * * * \\
(10.40)\end{array}$ & $\begin{array}{l}0.1101 * * * \\
(10.39)\end{array}$ \\
\hline Size & $\begin{array}{l}0.0498 * * * \\
(4.91)\end{array}$ & $\begin{array}{l}0.0505^{* * *} \\
(4.99)\end{array}$ & $\begin{array}{l}0.0392 * * * \\
(4.21)\end{array}$ & $\begin{array}{l}0.0418^{* * * *} \\
(4.29)\end{array}$ & $\begin{array}{l}0.0407 * * * \\
(3.92)\end{array}$ \\
\hline D_Leverage & $\begin{array}{l}0.4332 * * * \\
(2.93)\end{array}$ & $\begin{array}{l}0.4320^{* * *} \\
(2.92)\end{array}$ & $\begin{array}{l}0.3945^{* * *} \\
(2.67)\end{array}$ & $\begin{array}{l}0.3622 * * \\
(2.44)\end{array}$ & $\begin{array}{l}0.3634 * * \\
(2.45)\end{array}$ \\
\hline Sales_Growth & $\begin{array}{l}0.2736^{* *} \\
(2.17)\end{array}$ & $\begin{array}{l}0.2755^{* *} \\
(2.18)\end{array}$ & $\begin{array}{l}0.3203^{* *} \\
(2.57)\end{array}$ & $\begin{array}{l}0.3211^{* *} \\
(2.48)\end{array}$ & $\begin{array}{l}0.3274 * * \\
(2.53)\end{array}$ \\
\hline Payment_Cash & $\begin{array}{l}-0.1048 * * * \\
(-3.85)\end{array}$ & $\begin{array}{l}-0.1046 * * * \\
(-3.84)\end{array}$ & $\begin{array}{l}-0.1057 * * * \\
(-3.88)\end{array}$ & $\begin{array}{l}-0.1073^{* * *} \\
(-3.89)\end{array}$ & $\begin{array}{l}-0.1074 * * * \\
(-3.90)\end{array}$ \\
\hline Payment_Stock & $\begin{array}{l}-0.0020 \\
(-0.05)\end{array}$ & $\begin{array}{l}-0.0022 \\
(-0.05)\end{array}$ & $\begin{array}{l}-0.0024 \\
(-0.06)\end{array}$ & $\begin{array}{l}-0.0043 \\
(-0.10)\end{array}$ & $\begin{array}{l}-0.0050 \\
(-0.12)\end{array}$ \\
\hline Tenure & $\begin{array}{l}-0.0063 \\
(-0.66)\end{array}$ & $\begin{array}{l}-0.0066 \\
(-0.69)\end{array}$ & $\begin{array}{l}-0.0064 \\
(-0.67)\end{array}$ & $\begin{array}{l}-0.0055 \\
(-0.58)\end{array}$ & $\begin{array}{l}-0.0053 \\
(-0.55)\end{array}$ \\
\hline Overconfidence & $\begin{array}{l}-0.0371 \\
(-1.12)\end{array}$ & $\begin{array}{l}-0.0381 \\
(-1.15)\end{array}$ & $\begin{array}{l}-0.0255 \\
(-0.84)\end{array}$ & $\begin{array}{l}-0.0322 \\
(-1.00)\end{array}$ & $\begin{array}{l}-0.0352 \\
(-1.06)\end{array}$ \\
\hline
\end{tabular}


Table 6 (continued)

\begin{tabular}{llllll}
\hline Variable & D_Risk Model 1 & D_Risk Model 2 & D_Risk Model 3 & D_Risk Model 4 & D_Risk Model 5 \\
\hline $\begin{array}{l}\text { Number of observa- } \\
\text { tions }\end{array}$ & 6431 & 6431 & 6432 & 6265 & 6265 \\
$\begin{array}{l}\text { F-statistic } \\
\text { R-squared }\end{array}$ & $5.52^{* * *}$ & $5.53^{* * *}$ & $6.09^{* * *}$ & $5.63^{* * *}$ & $7.23^{* * *}$ \\
$\begin{array}{l}\text { Industry fixed } \\
\text { effects }\end{array}$ & 0.076 & 0.076 & 0.074 & 0.074 & 0.074 \\
\hline
\end{tabular}

The table presents multivariate analysis of the change in risk of acquiring firms included in the sample of 7747 acquisitions completed during the period January 1, 1993, to December 31, 2010 from SDC Platinum. Variable definitions are presented in Table 14. t-statistics based on robust standard errors are in parenthesis. $* * *, * *$ and $*$ indicate statistical significance at the $1 \%, 5 \%$ and $10 \%$ levels respectively

we expect that our results are not driven by reverse causality. ${ }^{15}$ However, it is possible that compensation committees changed risk-taking incentives in anticipation of the stricter governance code brought by the passage of SOX. Therefore, in this section we perform some further testing to confirm that our findings are robust to endogeneity concerns.

\subsubsection{Changes in the propensity to undertake risky investments post-SOX}

It is possible that managers are less inclined to undertake risky investments post-SOX due to the personal costs of undertaking value-destroying projects in this period (Shadab 2008; Bargeron et al. 2010; Arping and Sautner 2013). If so, this creates a problem of selection bias in our earlier findings. To address this concern, we estimate acquisition probability for the full panel of ExecuComp firm-years from probit models estimated using the explanatory variables outlined in Harford (1999), which we supplement with incentive compensation and the SOX dummy variable. We also add Overconfidence as an explanatory variable to control for the fact that SOX may affect the decision to acquire by restraining CEO confidence (Banerjee et al. 2015). The dependent variable is a dummy equal to one if a firm undertakes an acquisition during the financial year, and zero otherwise.

Table 15 present the results of the probit models. Our results confirm that risk-taking incentives stemming from executives' equity and option portfolio can induce acquisition activity (Boulton et al. 2014; Croci and Petmezas 2015). In particular, Models 1-4 show that both new and accumulated incentives are positively related to the propensity to acquire while Model 5 provides support to the findings of Croci and Petmezas (2015) that it is the pay-risk sensitivity (Vega) that makes executives more acquisitive. With regard to the control variables, we find a positive relation between acquisition probability and firm size, cash ratio, and revenue growth (Harford 1999). On the other hand, the probability of acquisition decreases with book-to-market ratio and leverage (Uysal 2011). The Overconfidence variable is positive and significant at the one percent level in all models confirming that overconfident CEOs have a higher propensity to acquire (Malmendier and Tate 2008; Billett and Qian 2008). Once we control for executive compensation and CEO overconfidence,

\footnotetext{
15 Similar arguments are made elsewhere in the literature when SOX is used as an exogenous shock (see, for instance; Guo et al. 2015; Banerjee et al. 2018; Hege et al. 2021).
} 


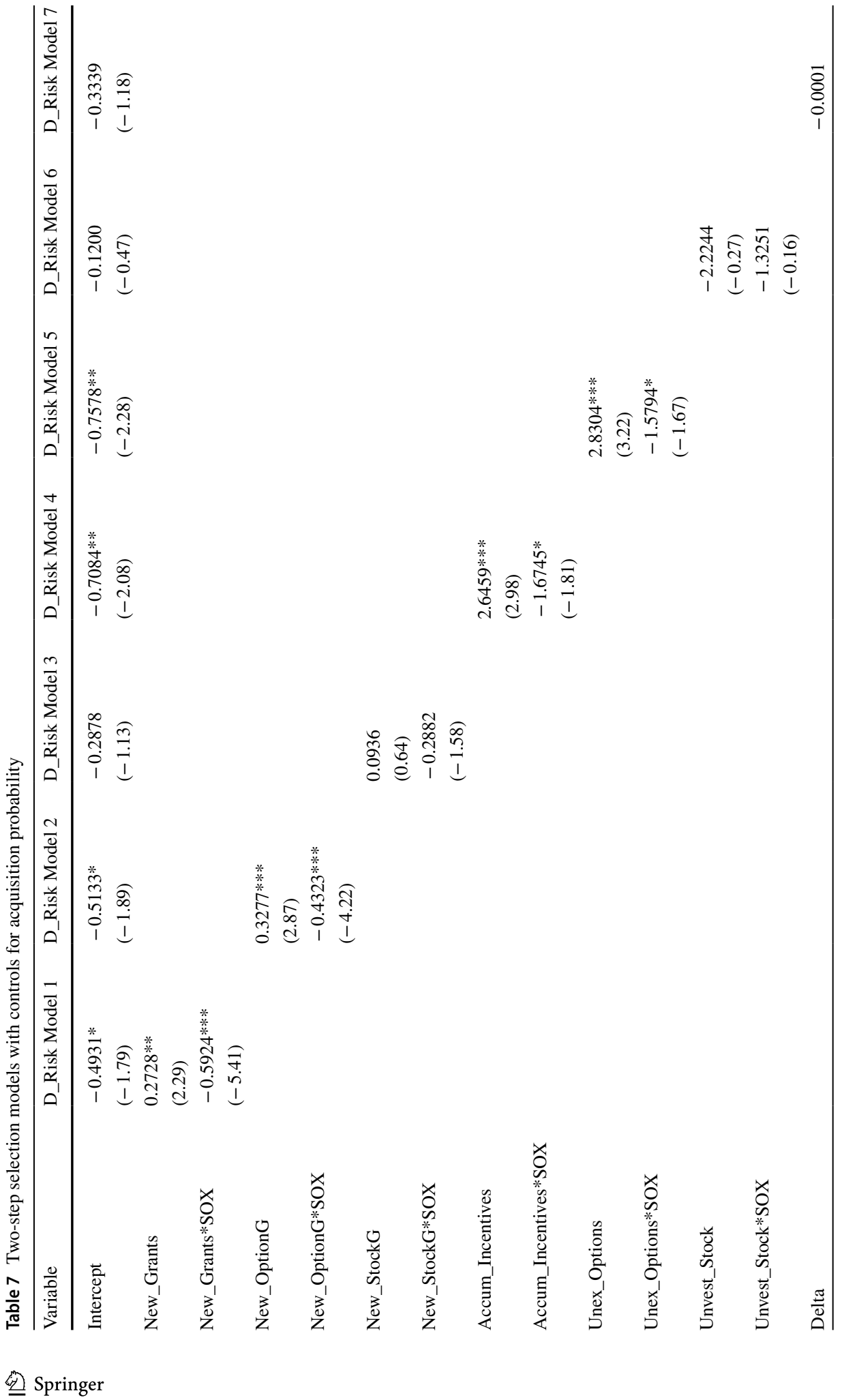




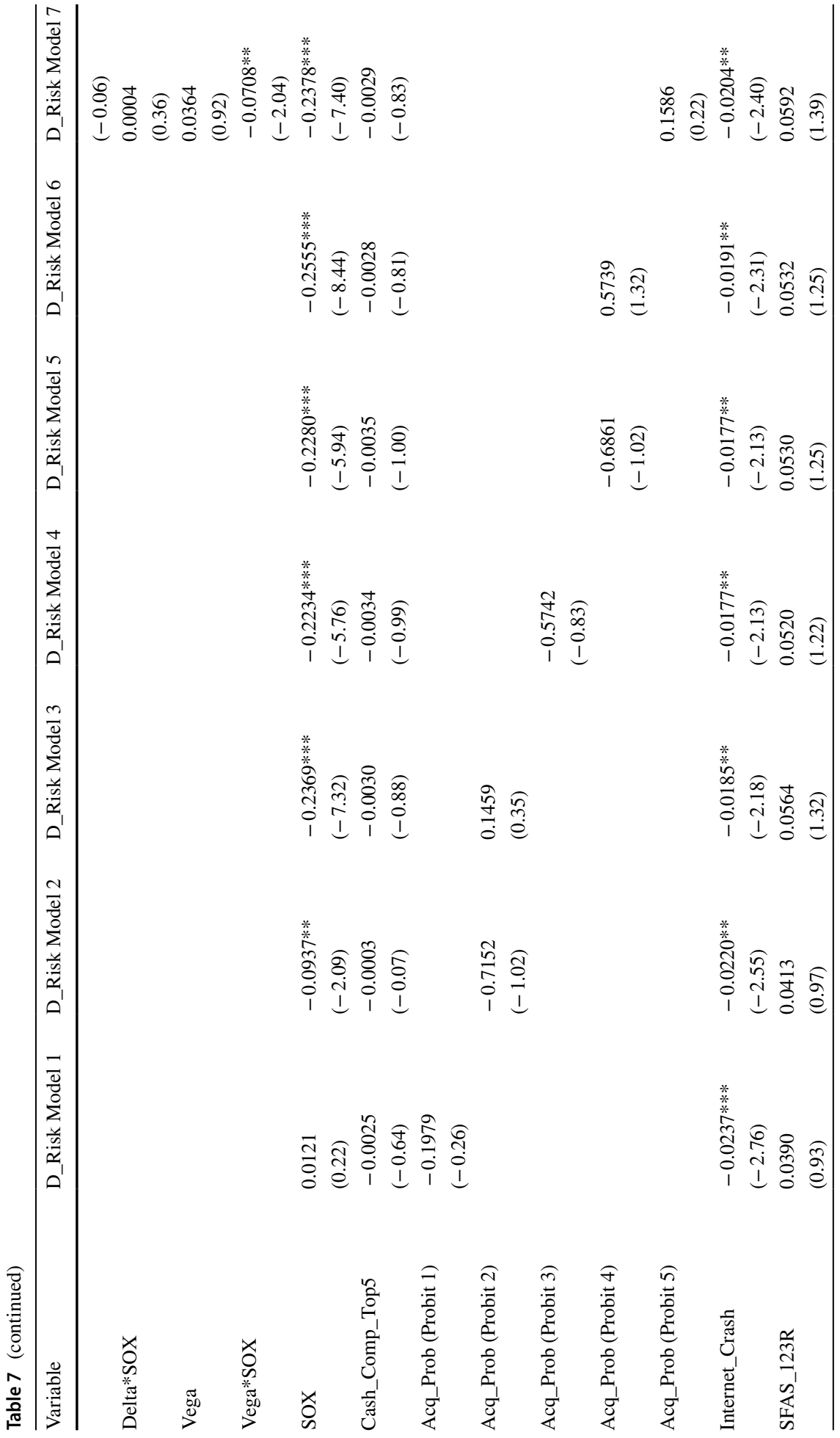




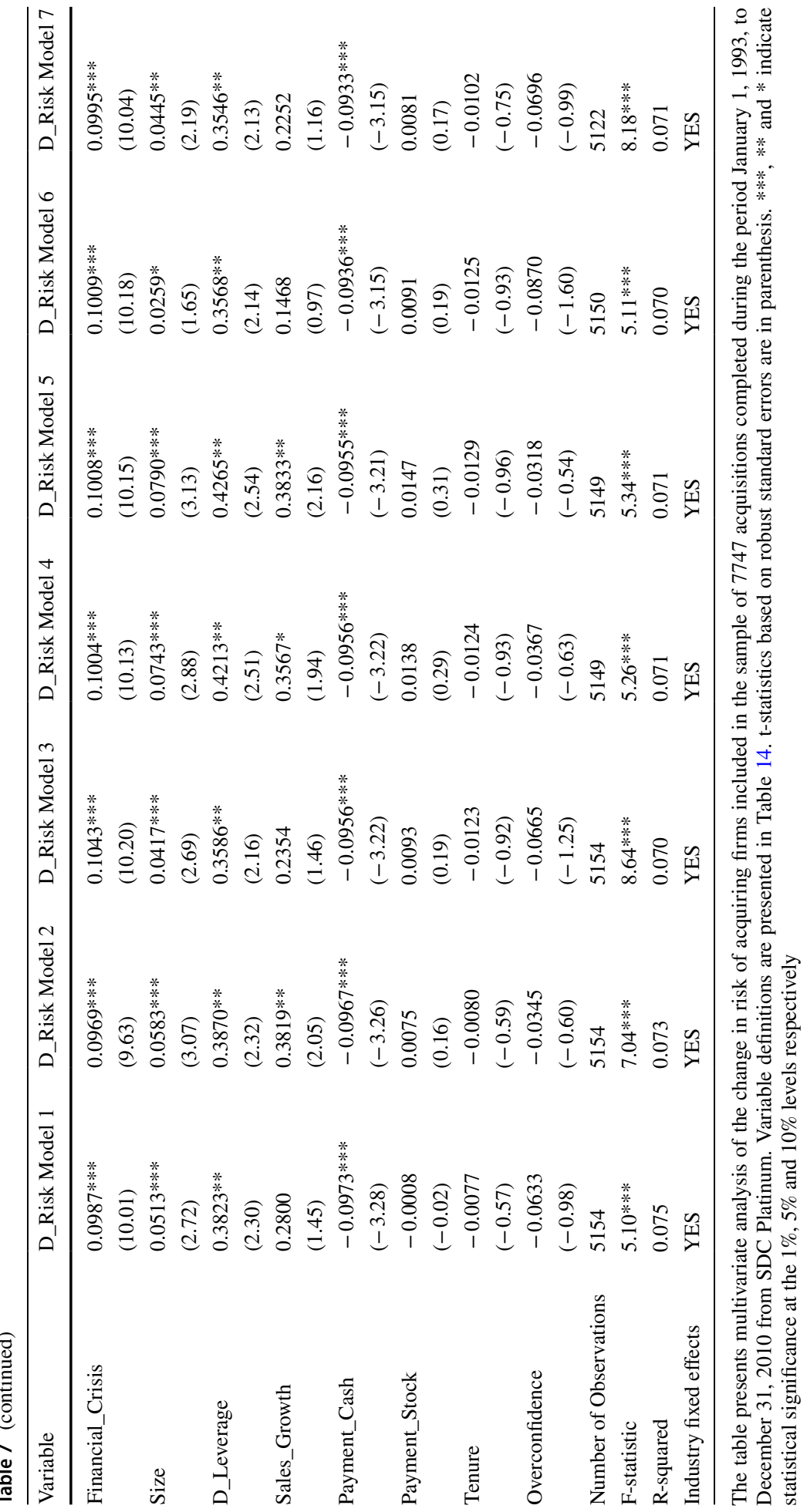


SOX does not have an important impact on acquisitiveness, consistent with the findings of Banerjee et al. (2015).

From these models, we predict the likelihood of undertaking an acquisition for each firm-year observation in our main sample. We label this variable Acq_Prob. If SOX reduces the probability of undertaking acquisitions via changes in managerial incentives, this endogenously determined control variable should reduce concerns surrounding selection bias in our acquisition sample. Sample size is reduced to 5631 observations in this test due to data requirements for the estimation of Acq_Prob.

We present the results in Table 7 and confirm that our findings hold across all optionbased incentive measures Specifically, we find that post-acquisition changes in firm risk are positively related to new stock option grants (Models 1 and 2), accumulated unexercised options (Model 4 and 5) and Vega (Model 7) before SOX, but the relation between these compensation incentives and acquisition risk changes significantly post-SOX. We do not find any statistically significant relation between stock grants and risk-taking surrounding the passage of SOX (Model 3 and 6).

\subsubsection{System of simultaneous equations}

In this section we perform additional testing to rule out the possibility that the simultaneous determination of managerial incentives and risk-taking affects our results. Following Rogers (2002) and Coles et al. (2006), we use a three-stage-least-squares (3SLS) system of simultaneous equations to estimate the determinants of contemporaneous incentive compensation and changes in post-acquisition firm risk (D_Risk). Our incentive compensation measures, New_Option ${ }^{c},{ }^{16}{ }^{N}$ New_Stock $G^{c}$, Unex_Options ${ }^{c}$, Unvest_Stock $^{c}$, Delta $^{c}$ and $V_{e g a}{ }^{c}$ and the change in acquisition risk (D_Risk) are endogenous variables in the threestage-least-squares (3SLS) model. The independent variables used to explain changes in firm risk surrounding acquisition decisions are the same as in the preceding analysis. Control variables for managerial incentives are in line with prior literature on executive compensation and corporate investments (see Coles et al. 2006; Croci and Petmezas 2015).

Table 8 presents the results. In line with our earlier findings, we document a positive relation between equity incentives and acquisition risk, which becomes weaker after the passage of SOX. Panel A presents the results for new incentive grants, Panel B for accumulated incentives and Panel C for Delta and Vega. In all three Panels, the option-based incentives are positively related to risk-taking before SOX but this relation shows a significant weakening after the passage of the Act. The coefficients of New_Option $G^{c}$,Unex_Options ${ }^{c}$ and $\mathrm{Vega}^{c}$ are positive and statistically significant at the $1 \%$ level while their interactions with SOX are negative and significant also at the 1 present level.

Furthermore, the results confirm our conjecture that the observed risk aversion of managers post-SOX stems from their option portfolio. For instance, Panel B shows that the pre-SOX positive impact of incentive compensation on risk-taking is pronounced on unexercised options. Post-SOX however, an increase in executives' holdings of unexercised options leads to a decrease in the riskiness of acquisition decisions. On the other hand, the coefficient on unvested stock is significant only at the $10 \%$ level and its interaction with SOX indicates a positive switch towards risk-taking which cannot explain the observed decrease in acquisition risk post-SOX. Similarly, Panel C shows a positive relation between

16 The superscript symbol "c" denotes contemporaneous values. 


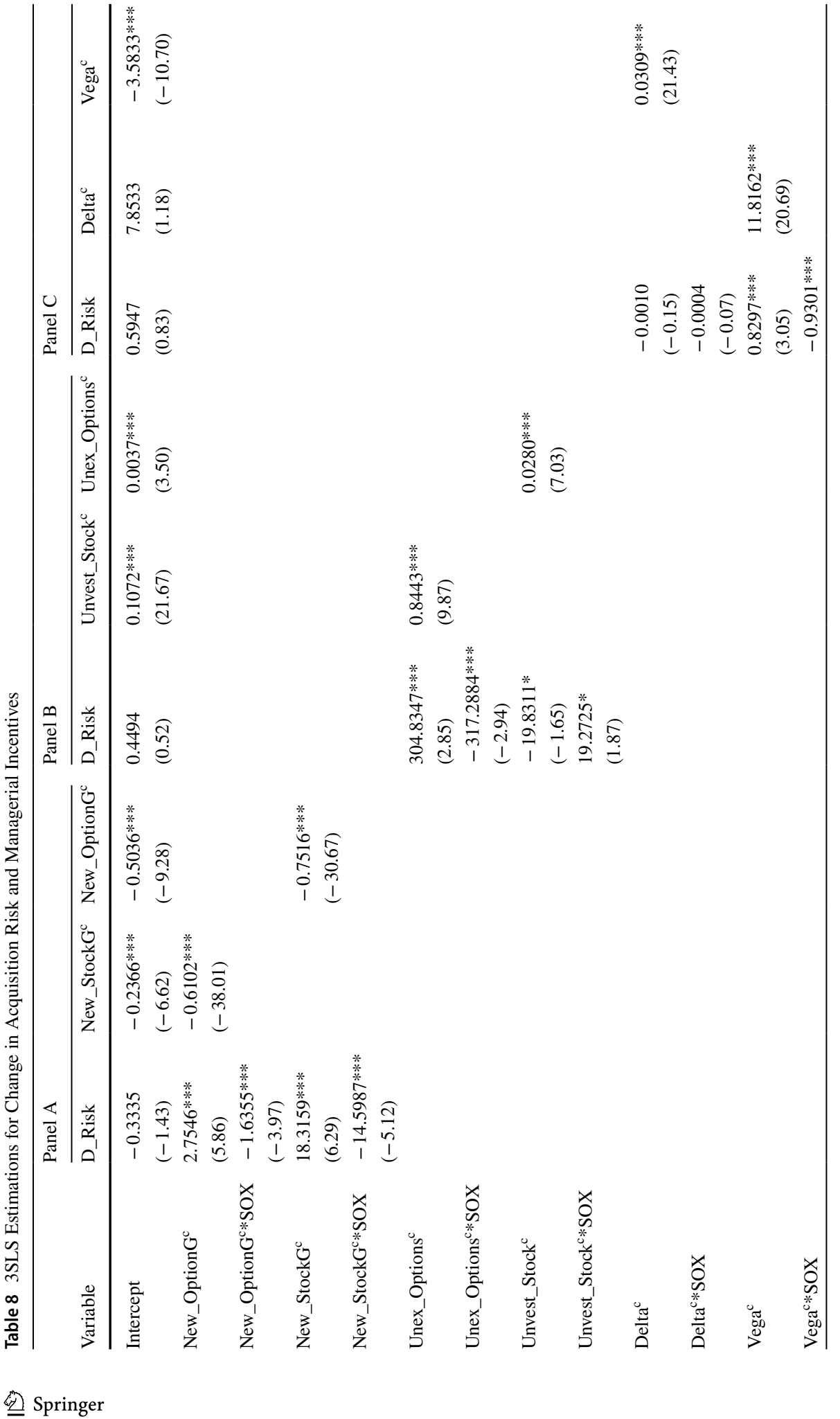




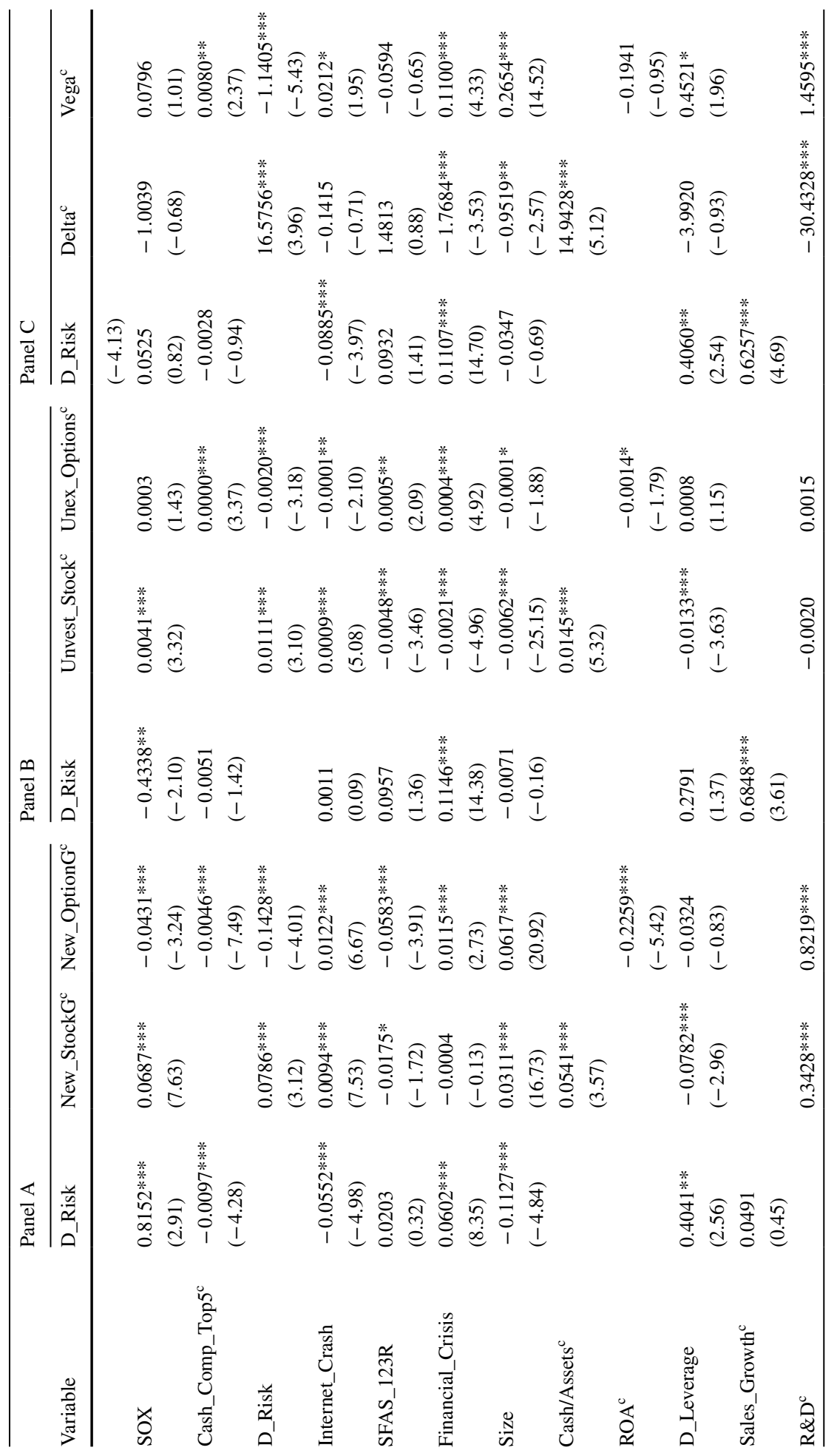




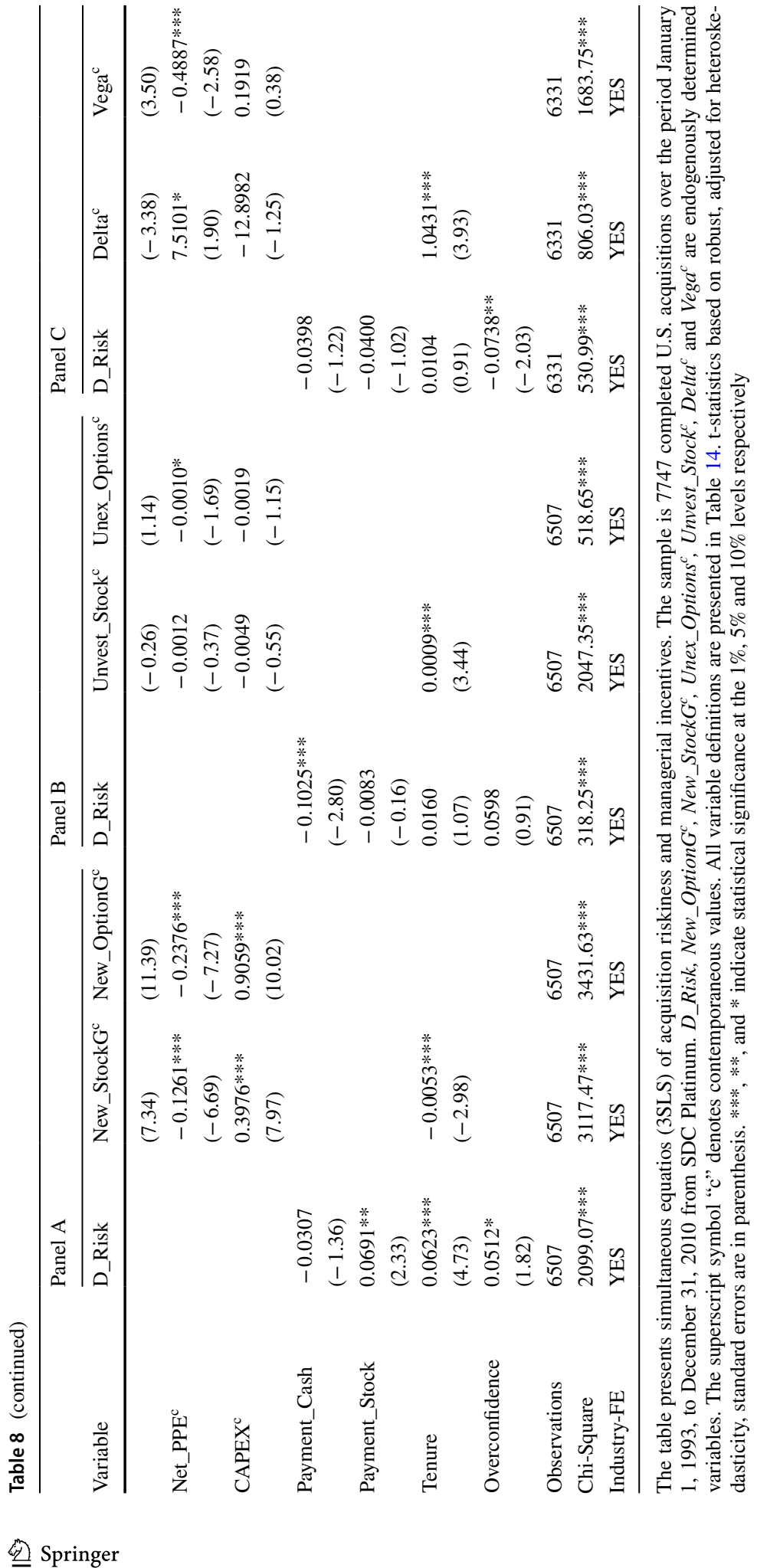


Vega and acquisition risk before SOX but this relation weakens significantly post-SOX with the coefficient of Vega*SOX being negative and significant at the $1 \%$ level. In line with our earlier results, we find no relation between Delta and changes in firm risk surrounding acquisitions. Overall, these results confirm our core finding that SOX weakened the positive relation between option-based incentives and risk-taking activity.

\subsubsection{Predicted incentives and propensity score matching}

To alleviate remaining concerns that our results reflect a spurious relation between equity incentives and risk-taking, we conduct two additional endogeneity tests in this section. The first test uses optimal levels of endogenously predicted equity incentives to test their impact on risk-taking surrounding the passage of SOX. We follow Core and Guay (1999) to predict managerial incentives, based on a number of firm characteristics, and we use these predicted values as instruments of equity-based compensation to re-examine our findings. In addition, we control for the impact of market wide movements on investment risk using a propensity score matched abnormal returns-based risk measure (D_Risk_PSM).

Panel A in Table 9 presents the results. The interaction term of Pred_New_Grants and SOX in Model 1 is negative and statistically significant at the $1 \%$ level showing that new equity grants awarded after the passage of SOX adversely affect risk-taking activity. Models 2 and 3 confirm that the change in the relation between equity incentives and risk taking stems from the executives' option portfolio with the coefficient of Pred_New_OptionG*SOX being negative and statistically significant at the $1 \%$ level. On the other hand, the coefficient of Pred_New_StockG*SOX in Model 3 is not significant at conventional levels. Models 4-6 show that predicted changes in both pay-performance (Pred_Delta) and pay-risk (Pred_Vega) sensitivity can explain the reduced risk-taking activity post-SOX. However, the impact of Vega remains economically more important. Model 6, where we control for both Delta and Vega, shows that post-SOX one standard deviation increase in Pred_Delta leads to a 5\% decrease in $D \_R i s k \_A b R$, [i.e., $1.494 \times(0.0048-0.0391)]$ which is a $35 \%$ change relative to its mean. At the same time, one standard deviation increase in Pred_Vega is associated with an $8 \%$ decrease in $D_{-}$ Risk_AbR, [i.e., $0.269 \times(-0.0045-0.2928)]$ representing a 56\% change relative to its mean.

Our measures of post-acquisition changes in firm risk may also suffer from a selection bias if acquiring firms are materially different to non-acquiring firms. To address this concern, we construct a propensity score matched measure of abnormal stock price volatility. D_Risk_PSM is defined as the volatility of acquirer's excess stock returns for a 6-month period following the effective date $(+60$ to +185 trading days $)$ minus the volatility of acquirer's excess stock returns for a 6-month period preceding the announcement date ( -185 to -60 trading days). Excess returns are calculated as the bidder's daily returns minus those of the propensity-score matched firm for the same period. Similar to our $D_{-}$ Risk_AbR measure, the event period stops 60 trading days before the announcement date and starts again 60 trading days after the effective date to avoid the impact of acquisition negotiation and completion periods on our results (Kravet 2014). Propensity scores are estimated using Harford's (1999) model to predict bidders. The model is estimated separately for each year during our sample period and each acquirer is matched to the firm with the closest propensity score in the same industry-year that has not been involved in any M\&A activity for a period of three years surrounding the acquisition effective date. Matched firms that are delisted before the completion of 185 trading days following the acquisition are replaced with the next closest match on the delisting date. 


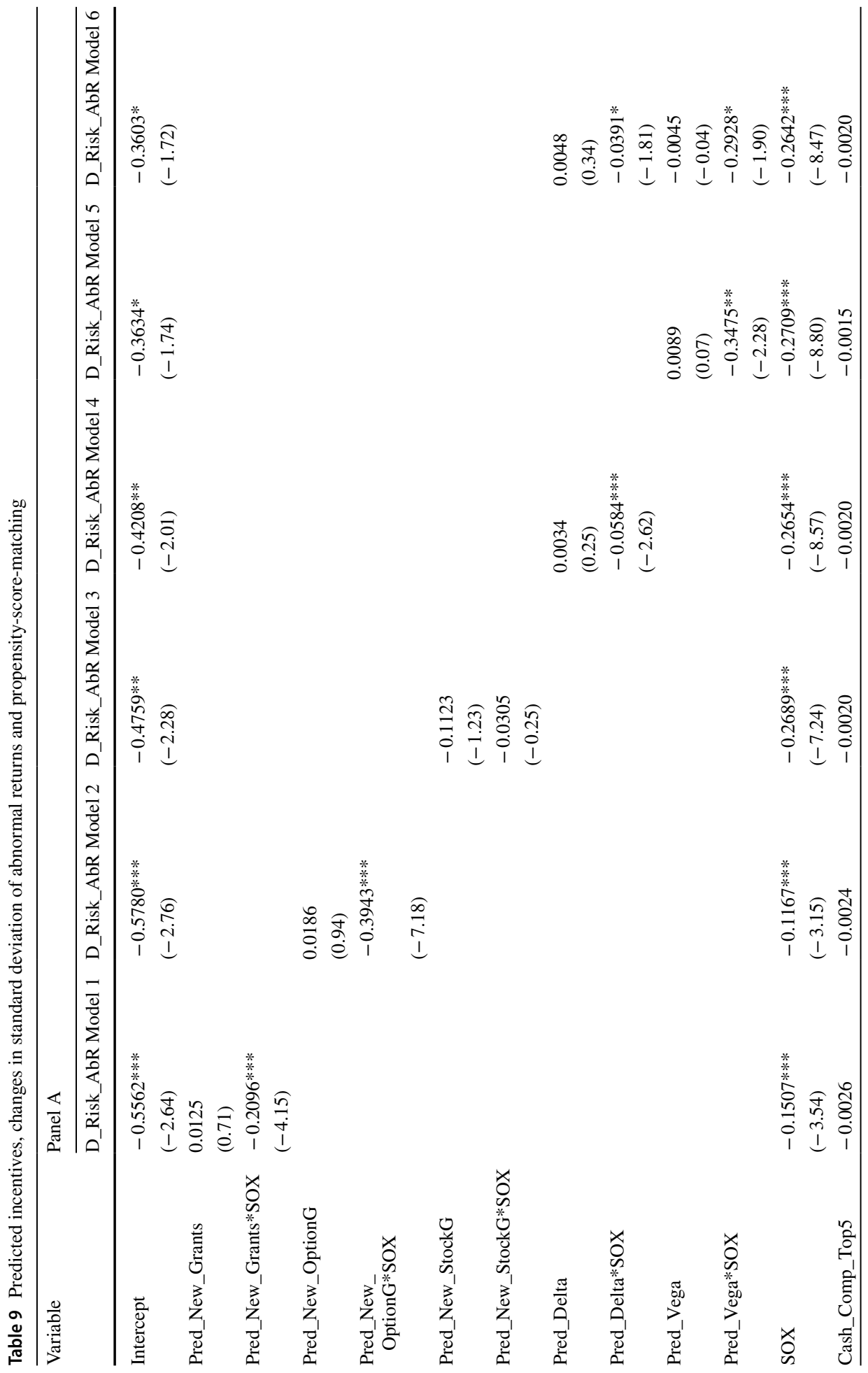




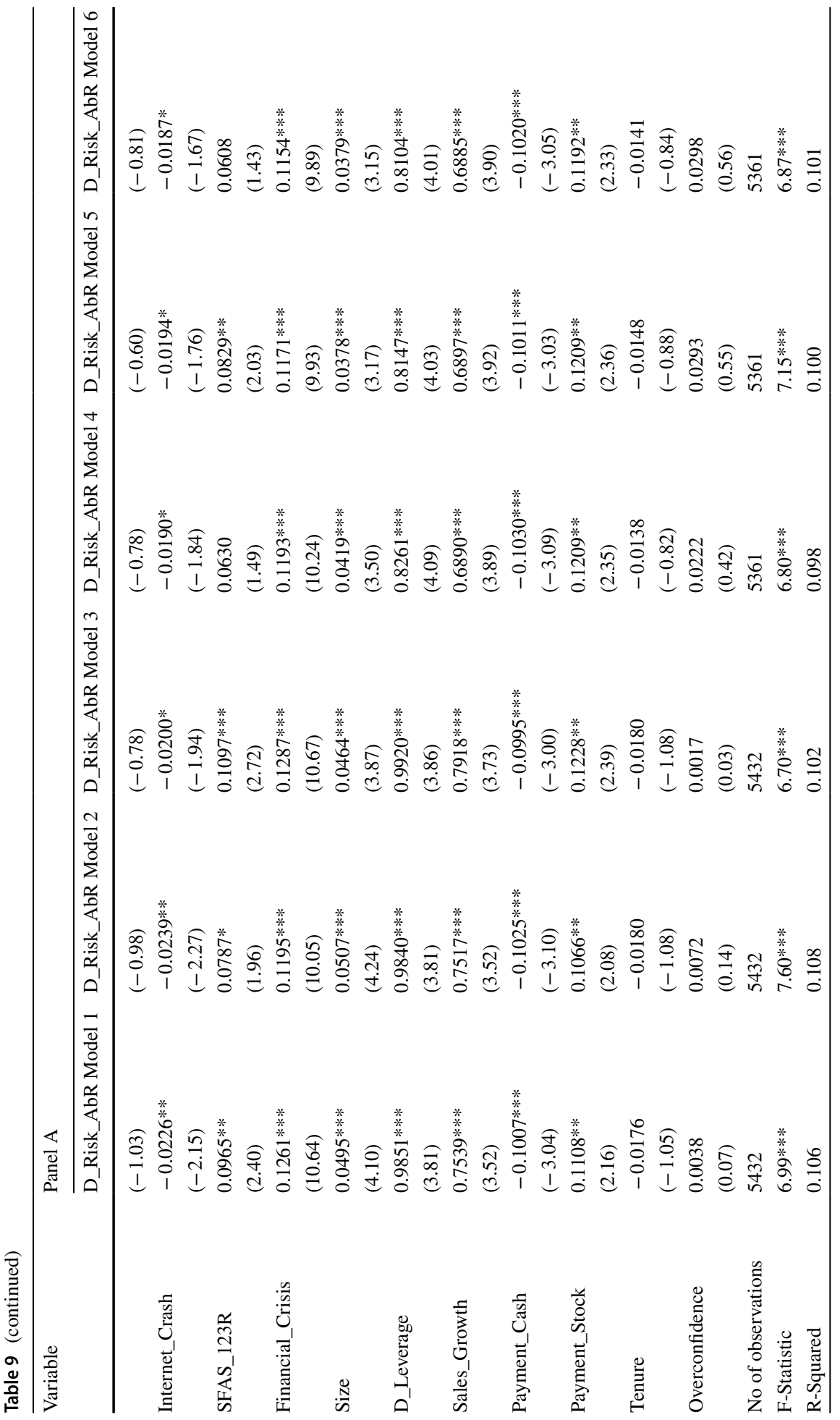




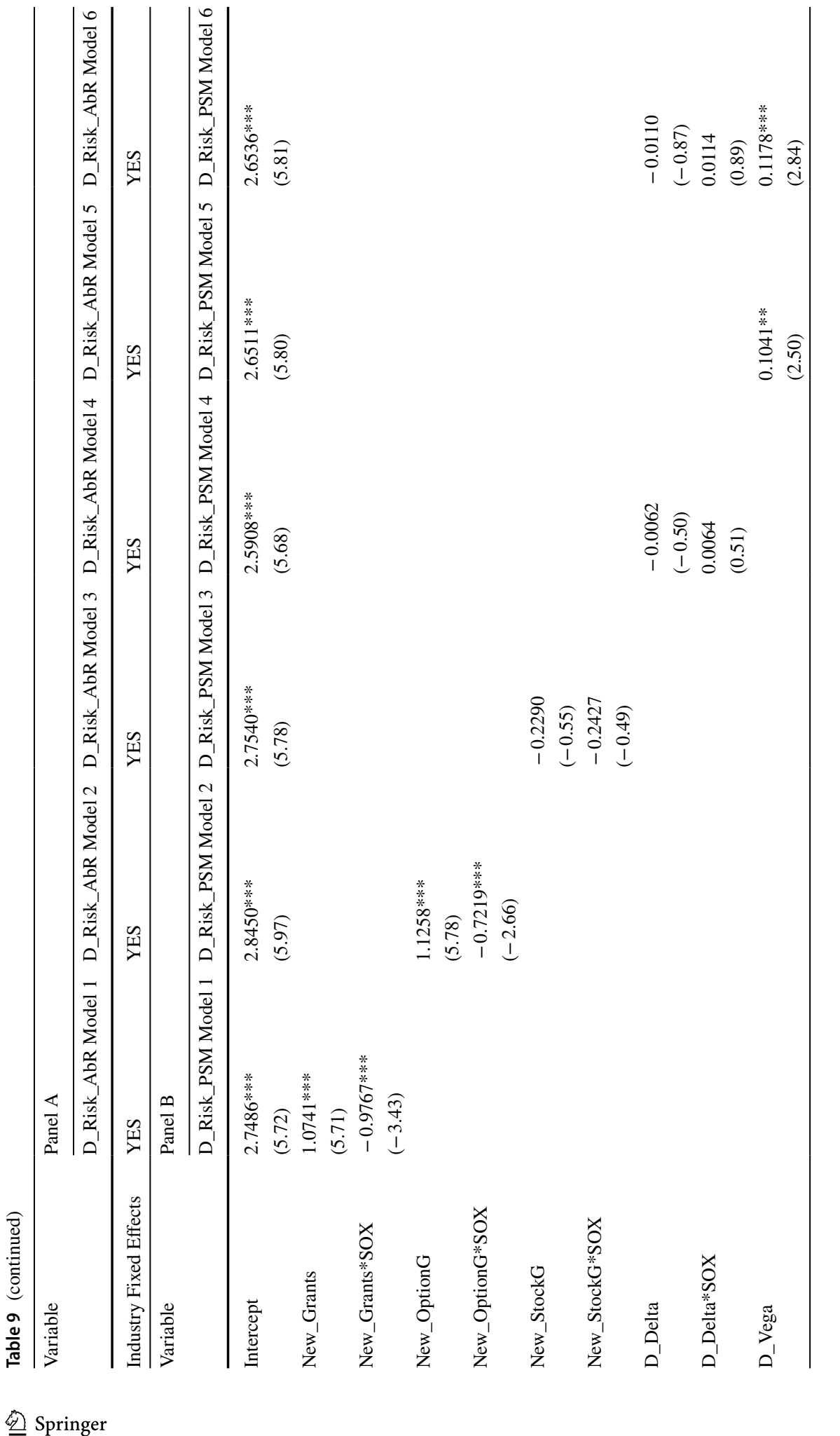




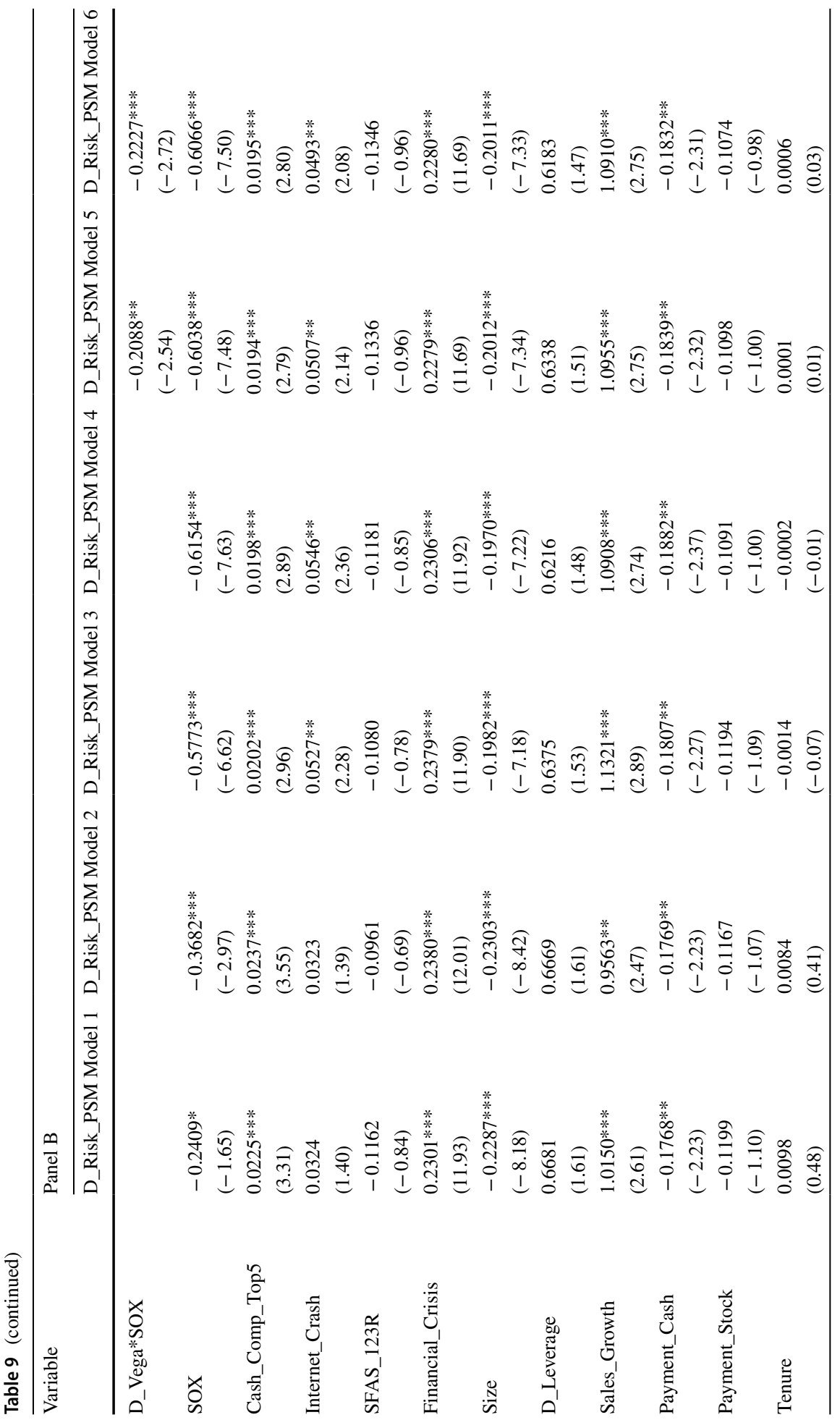




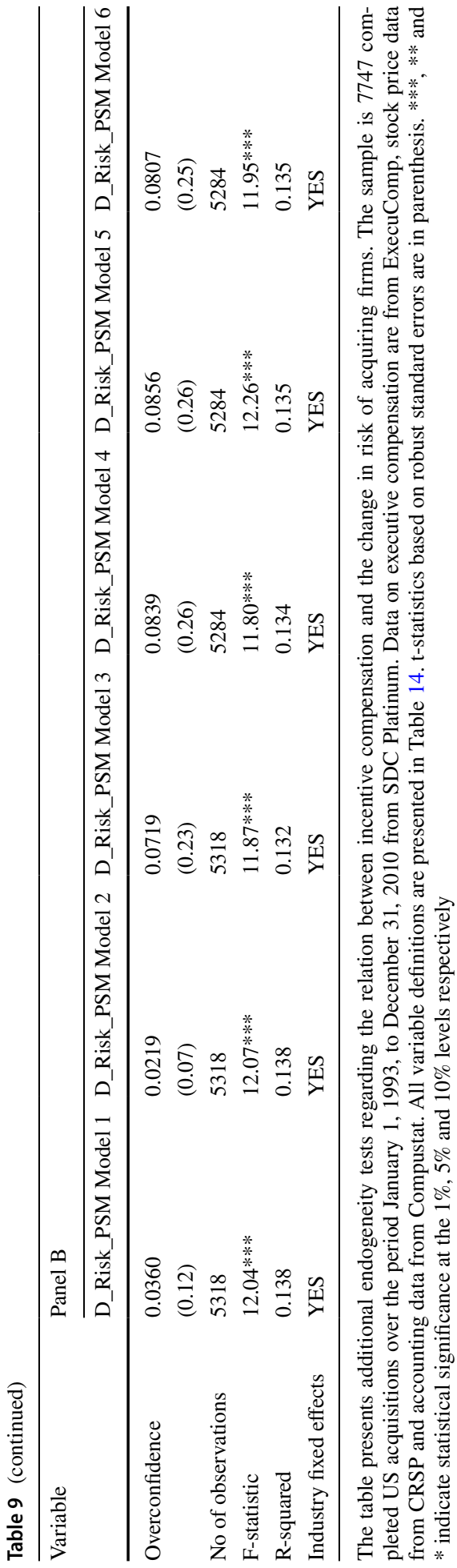


Panel B in Table 9 presents the results. Since we now control for selection bias in our dependent variable through propensity score matching, we use actual rather than predicted incentives as our main explanatory variables. The results confirm our main findings. Model 1 shows that new equity grants are positively associated with risk-taking before SOX but this relation is significantly weakened post-SOX with the coefficients of both New_Grants and New_Grants*SOX being statistically significant at the $1 \%$ level. Disentangling the components of new equity grants to new option grants and new restricted stock grants in Models 2 and 3 respectively confirms that the effect is driven by the option portfolios of executives. New_OptionG is positive and statistically significant at the $1 \%$ level while New_Options $G^{*} S O X$ is negative and statistically significant at the same level. In contrast, $N e w \_S t o c k G$ is not significantly associated with risk-taking either before or after SOX. To maintain consistency with Panel A, Models 4-6 examine the impact of changes in payperformance and pay-risk sensitivity on risk taking. Pay-performance sensitivity (Delta), that reflects executives' stock portfolio, does not have an important impact on risk-taking in Models 4 and 6. On the other hand, Pay-risk sensitivity (Vega), which stems from executives' option portfolio, shows a significant positive association with risk-taking before SOX but this relation shows a significant weakening post-SOX.

\subsubsection{Changes in risk-taking incentives}

As a final check to ensure that our results are not driven by changes in managerial compensation due to the M\&A transaction, we partition our sample into two sub-samples. The first sub-sample includes those acquiring firms that increase risk-taking incentives from the end of the year preceding the acquisition announcement $(t-1)$ to the end of the year following the completion of the deal $(t+1)$ with the second sub-sample including those firms that reduce risk-taking incentives for the same period. If our results are driven by underlying changes in managerial compensation, we should observe the risk-taking reduction post-SOX only for the sub-sample of firms that reduce risk-taking incentives. However, repeating our analysis only for the sub-sample of firms that increased risk-taking incentives leaves our results unchanged. Our sub-sample results confirm that risk-taking incentives are positively related to risk-taking activity before SOX but their interaction with SOX becomes negative and statistically significant even if firms have increased risk-taking incentives in the same period. ${ }^{17}$ The sub-sample analysis also confirms that the change in the way managers respond to risk-taking incentives stems from their option portfolio in line with our earlier results.

Collectively, the results of the sub-sample analysis along with all endogeneity tests presented in Sect. 5.1. confirm that our findings are robust to a number of alterative tests to assess causality and provide supportive evidence that our results are not driven by underlying changes in managerial compensation. Managers respond differently to risk-taking incentives post-SOX with the increased managerial risk-aversion being evident even for those managers that receive higher risk-taking incentives in the same period.

17 The results are available in Tables $4 \mathrm{~d}$ and $6 \mathrm{~d}$ of our Online Appendix. 


\subsection{Alternative acquisition risk measures}

In addition to the risk measures presented in Table 9, D_Risk_AbR and $D \_R i s k \_P S M$, in this section we examine the cross-sectional dispersion of post-acquisition stock returns as an alternative measure of acquisition risk. Following Yung et al. (2008) we propose that uncertainty will lead to greater variation in the quality of acquisition decisions resulting in a higher dispersion of post-acquisition stock returns. Therefore, we expect the adverse impact of SOX on risk-taking to be reflected in a reduction in the dispersion of post-acquisition performance following the implementation of the Act. Following our prior results, we expect this effect to be most pronounced in the group of highly incentivized managers.

We calculate the cross-sectional standard deviation of acquirer daily cumulative abnormal returns (CARs) for four different time intervals beginning one day following the announcement date: 3, 6, 9 and 12 months. We calculate CARs using a daily market model where the market return is drawn from the CRSP value-weighted index and an estimation period from 200 to 60 days before the announcement. ${ }^{18}$

We present these findings in Table 10. Panels A and B report our findings for the preSOX and post-SOX periods respectively, and panel $\mathrm{C}$ examines differences in post-acquisition return dispersion between the post- and pre-SOX periods for high and low incentivized managers. Consistent with our predictions, we find that pre-SOX, high Delta and Vega encourage managers to take on more risky acquisitions, which results in greater dispersion of post-acquisition outcomes in comparison to low incentivized managers. Focusing on Vega for instance, the standard deviation of post-acquisition 12-month CARs is 0.404 for high incentivized managers, which is greater than the figure of 0.383 for low Vega managers and the difference is significant at the 5\% level. However, the effect reverses post-SOX, such that high-incentivized managers make less risky acquisitions based on the dispersion of post-acquisition returns. For 12-month CARs, the cross-sectional standard deviation of post-acquisition returns for high Vega managers is 0.266 , which is significantly lower than the corresponding figure of 0.340 for low Vega managers.

In Panel C, we report differences in standard deviation of post-deal returns between postSOX and pre-SOX periods. 15 out of 16 differences between pre- and post-SOX acquisitions in Panel $\mathrm{C}$ are significant providing strong evidence that acquisition risk declined after the passage of SOX. Notably, the economic size of the risk decline is approximately three times larger for high-incentivized managers relative to their low incentivized counterparts, confirming that SOX has significantly affected the way managers perceive compensation contracts that are notionally set-up to encourage risk seeking investment decisions. Collectively, the results in Tables 9 and 10 confirm that our main findings are robust to the definition of risk and test design to examine changes in firm risk surrounding corporate acquisitions. ${ }^{19}$

\footnotetext{
${ }^{18}$ Our results are unchanged if we measure abnormal returns starting from one day after the effective, rather than the announcement, date and if we examine abnormal buy-and-hold returns benchmarked against an industry, size, and book-to-market matched control firm. They are also unchanged if we define high and low compensation firms separately within the pre-SOX and post-SOX groups, rather than for the full sample of firms.

${ }^{19}$ Related to the changing financing of mergers, we also consider if the propensity to de-leverage business risk through asset divestitures following mergers has changed surrounding SOX. We collect data on asset divestitures from SDC Platinum following the identification process outlined in Borisova et al. (2013) and where the bidder has either announced or completed a divestiture in the 6-month post-merger period from the effective date. This results in 964 observations. 582 of the divestitures in our sample occurred in the pre-SOX period and 382 take place post-SOX, suggesting no obvious increase in the propensity to divest
} 


\subsection{Timeliness of SOX}

Following prior research, we treat the passage of the Sarbanes-Oxley Act as a clean event (Chhaochharia and Grinstein 2009; Dicks 2012; Cohen et al. 2013) and identify pre- and post-SOX mergers as those occurring before and after July 30, 2002. Although the period leading up to SOX began with the dotcom collapse in 2000, Wintoki (2007) identifies the formal and value relevant information from the proposals, development and enactment of SOX as being released over a relatively short period between January 15 and August 15, 2002. Nejadmalayeri et al. (2013) describe the passage of the Act as having been passed in record time in comparison to legislation of comparable scope.

Nonetheless, Leuz and Wysocki (2016) highlight a number of potentially confounding events that led to SOX, which potentially weaken our ability to draw causal inference from the Act to management compensation incentives to undertake risky investment decisions. We aim to address the issue in base testing with controls for the internet crash of 2001, the introduction of SFAS No. 123R, and the global financial crisis of 2007-2008.

To examine the robustness of our assumption regarding the speed of SOX and its impact on how managers respond to compensation incentives, we follow the approach of Nejadmalayeri et al. (2013) who introduce a series of annual post-SOX dummy variables to verify if the SOX effect occurs in each year. The dummies are labelled SOXyear for the years 2002b, 2003, 2004 and 2005 respectively to reflect the specified calendar years and the period August 1, 2002 to December 31, 2002 following the passage of the Act. We report these results in Table 11.

Supporting our interpretation that SOX has an immediate effect, we find that the interaction between SOX2002b and incentive compensation is negative and significant at the $1 \%$ level, highlighting the structural change in the relation between equity incentives and risktaking. The negative interaction terms are also significant for the years 2003 and 2004 and confirm the effect is long-lasting. Our findings support the view that SOX had an immediate and permanent impact on corporate behavior. ${ }^{20}$

\footnotetext{
Footnote 19 (continued)

risky assets during the post-SOX period. The risk-reduction we observe post-SOX is concentrated in nondivesting firms rather than divesting firms. Therefore, our main results are not driven by firms taking on excessive risk during both periods but being more willing to divest this during the post-SOX period. We also consider whether changes in risk post-acquisition are driven by simultaneous changes in the method of payment or firm leverage surrounding SOX. We find that post-SOX there is a decline in propensity to undertake entirely stock financed acquisitions and a simultaneous increase in the frequency of all-cash deals, but we find no evidence that post-acquisition changes in leverage vary surrounding SOX. To examine whether the change in method of payment affects our earlier results, we re-estimate the main regression in Table 4 with additional controls for the interaction of D_Leverage, Payment_Cash, and Payment_Stock with the SOX dummy. The interaction terms are insignificant in all models and their inclusion does not affect the relation between incentive compensation, SOX and post-acquisition changes in risk.

${ }^{20}$ In further testing, we repeat the analysis dropping the years 1999-2001 to remove the dotcom period and 2007-2010 to remove the financial crisis period and any associated bias caused by their inclusion. Our results continue to hold. We also redefine the period covered by our SOX dummy over shorter windows from August 2002 to December 2003, 2004 and 2005 respectively. Our results continue to hold for these alternative windows.
} 


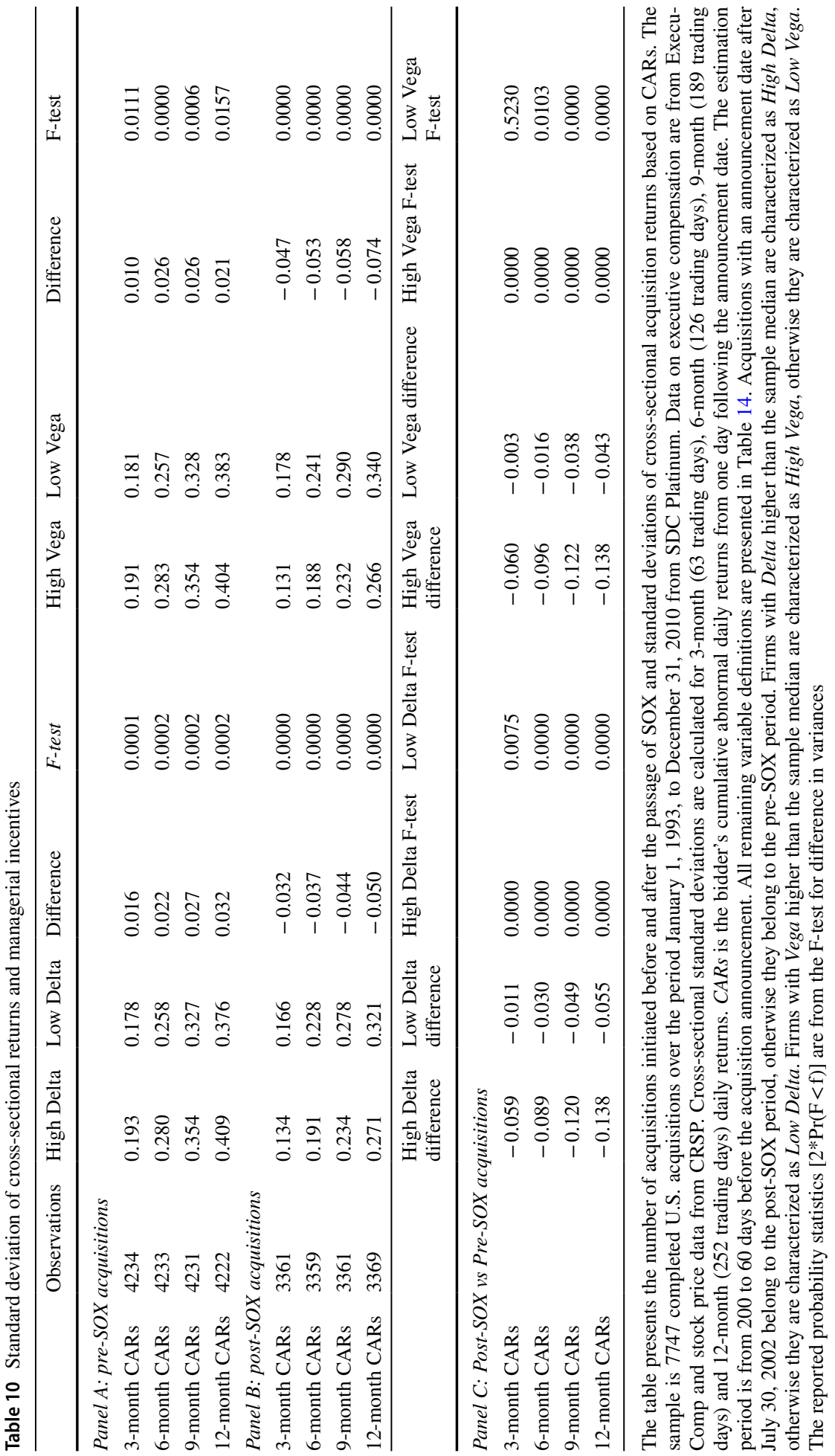




\section{Impact of SOX on post-acquisition performance}

Our findings so far show that SOX leads to a reduction in the incentive for corporate managers to undertake risky acquisition investments, which stems from executives' option portfolio. Research on merger activity shows that risky transactions can be value destroying over the long-term for acquiring firm shareholders (Moeller et al. 2005; Bouwman et al. 2009). If this is the case, then our results support the argument that firms and managers responded to SOX in a value-enhancing manner. Alternatively, corporate boards encourage managers to undertake value enhancing corporate investments, including some risky acquisitions, and therefore our findings could actually be an unwelcome development for firm shareholders. We examine the role of risk-taking incentives in the quality of merger in this section.

We study the wealth effects of SOX on acquiring firms using four performance measures. We measure long-run stock-price performance by $2 y r A B H R$, which is the 2-year daily buy-and-hold return of the acquiring firm beginning one day following the acquisition effective date minus the return of a matched firm over the same period. We select matched firms by industry, year, size and book-to-market ratio from a universe of firms that have not been involved in any acquisition activity for a period of 3 years surrounding the deal effective date. ${ }^{21}$ Following Bradley et al. (1988) and Golubov et al. (2012), we capture the total dollar gains for the bidder and the target from the transaction by the variable Synergies defined as the as the market value of equity 6 trading days before the acquisition announcement date times the cumulated abnormal returns over an 11-day window surrounding the announcement date $(-5,+5)$ for each firm. ${ }^{22}$ Cumulated abnormal returns are based on the market model using the CRSP value-weighted index. $D \_T F P$ measures the change in total factor productivity (TFP) from the end of the year preceding the acquisition announcement to the end of the year following the completion of the deal. Firm-year TFP data is from İmrohoroglu and Tuzel (2014) and estimations are based on the semiparametric procedure suggested by Olley and Pakes (1996) that controls for selection and simultaneity bias. ${ }^{23} \mathrm{We}$ gauge changes in operating performance by $D \_R O A$, defined as the difference in the return on assets (ROA) of the acquiring firm from the end of the year preceding the acquisition announcement to the end of the year following the completion of the deal.

Table 12 presents univariate results of the impact of SOX on the deal performance measures discussed above. We observe a general negative effect of the Act on the performance of acquiring firms. Before SOX, acquiring shareholders experience a positive and significant mean (median) $2 y r A B H R$ of $5.54 \%$ (2.71\%) while post-SOX $2 y r A B H R$ is not statistically different than zero. The mean (median) $2 y r A B H R$ decreases by $6.40 \%(3.25 \%)$ between the pre and post-SOX period and the difference is significant at the $1 \%$ level. In addition, merged firms experience lower synergy gains post SOX but the difference is not significant at conventional levels. The passage of SOX has also a negative impact on median TFP and the difference is significant at the $10 \%$ level. On the other hand, we

\footnotetext{
21 These matching criteria are consistent with those used in previous relevant studies (Barber and Lyon 1997; Spiess and Affleck-Graves 1999; Datta et al. 2001; Harford and Li 2007; Billett et al. 2010; Duchin and Schmidt 2013).

${ }^{22}$ We exclude the value of the target shares held by the acquirer before the transaction from the estimation of target's synergy gains.

23 We are grateful to İmrohoroglu and Tuzel (2014) for making their data publicly available.
} 
observe a small improvement in operating performance (ROA) but the change between the pre and post-SOX period is not significant.

Weaker acquisition performance in the post-SOX period may be due to a broader reduction in the set of profitable investment opportunities under the new regulatory environment rather than stemming from an adverse impact of SOX on the efficiency of incentive contracts to induce value-enhancing decisions. Therefore, we extend our analysis to a multivariate setting in Table 13 to test the role of risk-taking incentives in these effects and control for a number of factors that previous studies have identified as important determinants of deal performance (Travlos 1987; Jensen 1988; Morck et al. 1990; Harford 1999; Shleifer and Vishny 2003; Moeller et al. 2004; Officer 2007; Golubov et al. 2012).

We find a positive or neutral impact of risk-taking incentives on deal performance postSOX. More specifically, we find a positive impact of incentive pay on those performance measures that have experienced an important change post-SOX in our univariate analysis. For instance, in Model 1 of Table 13, the coefficient of New_OptionG is negative and significant at the $1 \%$ level but its interaction with SOX is positive and significant at the $5 \%$ level. Before SOX, one standard deviation increase in new option grants decreases $2 y A B H R$ by $4.7 \%$. However, post-SOX a similar change in new option grants improves $2 y A B H R$ by $0.4 \%$, a $16 \%$ change relative to its mean. Similarly, in Model 7 one standard deviation increase in new option grants before SOX decreases TFP by 0.048 , but post-SOX a similar change improves TFP by 0.005 , an $18 \%$ change relative to its mean. On the other hand, we do not observe an important impact of risk-taking incentives on synergies and ROA, which our univariate analysis in Table 12 shows have not been significantly affected by the passage of SOX.

What is worth noting is that these effects on deal performance have been transmitted through the same incentive channels that have been affected by SOX. As shown in our preceding analysis, the risk appetite of managers has decreased in the new regulatory environment via an important switch in the way they perceive risk-taking incentives provided by their option portfolio. In this section, we show that it is the same part of managerial compensation portfolio that drives improvements in long-term stock price performance and total factor productivity post-SOX. New option grants (Models 1 and 7), accumulated unexercised options (Model 8) and Vega (Models 3 and 9) are negatively associated with $2 y A B H R$ and $D \_T F P$ before SOX but the passage of the Act has significantly improved their impact on these performance measures. In contrast, we do not observe any important effect of managerial stock portfolio on deal performance post-SOX.

Overall, our results are supportive to the prediction that managers have responded to SOX in a value-enhancing manner. By discouraging investment in risky-projects, SOX has improved the efficiency of option-based incentives with regard to the quality of acquisition decisions. The passage of the Act has made excessively risky project less attractive to managers due to the higher underlying likelihood of value destruction switching their focus to less risky but value-enhancing choices. This is consistent with the view that excessive risktaking can have an adverse impact on performance (Shen and Zhang 2013; Bennett et al. 2015). In addition, we show that both the reduction in risk-taking activity and the improvements in stock-price performance and total factor productivity are driven by the executives' option portfolio. 
Table 11 Multivariate analysis of change in acquisition risk by year post-SOX

\begin{tabular}{|c|c|c|c|}
\hline Variable & D_Risk Model 1 & D_Risk Model 2 & D_Risk Model 3 \\
\hline Intercept & $\begin{array}{l}-0.2601 \\
(-1.21)\end{array}$ & $\begin{array}{l}-0.2487 \\
(-1.15)\end{array}$ & $\begin{array}{l}-0.2608 \\
(-1.21)\end{array}$ \\
\hline New_Grants & $\begin{array}{l}0.1349 * * \\
(2.04)\end{array}$ & & \\
\hline New_Grants*SOX2002b & $\begin{array}{l}-1.1075^{* * *} \\
(-4.31)\end{array}$ & & \\
\hline New_Grants*SOX2003 & $\begin{array}{l}-0.2956^{* *} \\
(-2.29)\end{array}$ & & \\
\hline New_Grants*SOX2004 & $\begin{array}{l}-0.3915^{* * *} \\
(-3.60)\end{array}$ & & \\
\hline New_Grants*SOX2005 & $\begin{array}{l}0.0698 \\
(0.54)\end{array}$ & & \\
\hline New_OptionG & & $\begin{array}{l}0.2101^{* * * *} \\
(3.31)\end{array}$ & \\
\hline New_OptionG*SOX2002b & & $\begin{array}{l}-1.1624 * * * \\
(-4.65)\end{array}$ & \\
\hline New_OptionG*SOX2003 & & $\begin{array}{l}-0.3863^{* * *} \\
(-3.16)\end{array}$ & \\
\hline New_OptionG*SOX2004 & & $\begin{array}{l}-0.4562 \text { *** } \\
(-4.41)\end{array}$ & \\
\hline New_OptionG*SOX2005 & & $\begin{array}{l}0.0126 \\
(0.10)\end{array}$ & \\
\hline New_StockG & & & $\begin{array}{l}-0.1983^{* *} \\
(-1.96)\end{array}$ \\
\hline New_StockG*SOX2002b & & & $\begin{array}{l}0.1512 \\
(0.26)\end{array}$ \\
\hline New_StockG*SOX2003 & & & $\begin{array}{l}0.3284 \\
(1.54)\end{array}$ \\
\hline New_StockG*SOX2004 & & & $\begin{array}{l}0.3381^{*} \\
(1.77)\end{array}$ \\
\hline New_StockG*SOX2005 & & & $\begin{array}{l}0.1403 \\
(0.73)\end{array}$ \\
\hline SOX $2002 b$ & $\begin{array}{l}-0.1721 \\
(-1.27)\end{array}$ & $\begin{array}{l}-0.2120^{*} \\
(-1.71)\end{array}$ & $\begin{array}{l}-0.7720^{* * *} \\
(-11.12)\end{array}$ \\
\hline SOX2003 & $\begin{array}{l}-0.2335^{* * *} \\
(-3.40)\end{array}$ & $\begin{array}{l}-0.2240^{* * *} \\
(-3.93)\end{array}$ & $\begin{array}{l}-0.3911^{* * *} \\
(-9.95)\end{array}$ \\
\hline SOX2004 & $\begin{array}{l}0.0638 \\
(1.13)\end{array}$ & $\begin{array}{l}0.0533 \\
(1.13)\end{array}$ & $\begin{array}{l}-0.1425^{* * *} \\
(-4.09)\end{array}$ \\
\hline SOX2005 & $\begin{array}{l}-0.1679 * * \\
(-2.49)\end{array}$ & $\begin{array}{l}-0.1345^{* *} \\
(-2.52)\end{array}$ & $\begin{array}{l}-0.1306^{* * *} \\
(-3.50)\end{array}$ \\
\hline Number of observations & 6434 & 6434 & 6434 \\
\hline F-statistic & $7.91 * * *$ & $8.01 * * *$ & $7.73 * * *$ \\
\hline R-squared & 0.086 & 0.087 & 0.084 \\
\hline Control variables & YES & YES & YES \\
\hline Industry fixed effects & YES & YES & YES \\
\hline
\end{tabular}


Table 11 (continued)

The table presents multivariate analysis of the change in risk of acquiring firms included in the sample of 7747 acquisitions completed during the period January 1, 1993, to December 31, 2010 from SDC Platinum. Variable definitions are presented in Table 14. t-statistics based on robust standard errors are in parenthesis. $* * *, * *$ and $*$ indicate statistical significance at the $1 \%, 5 \%$ and $10 \%$ levels respectively

Table 12 SOX and acquisition performance

\begin{tabular}{|c|c|c|c|c|c|}
\hline Compensation variable & Total sample & Pre SOX & Post SOX & Difference post vs pre & z/t Statistics \\
\hline \multicolumn{6}{|l|}{$2 y r A B H R(\%)$} \\
\hline Mean & $2.63 * * *$ & $5.54 * * *$ & -0.86 & $-6.40 * * *$ & -3.62 \\
\hline Median & $1.15^{* * *} *$ & $2.71 * * *$ & -0.54 & $-3.25^{* * *}$ & -2.64 \\
\hline Observations & 6889 & 3759 & 3130 & & \\
\hline \multicolumn{6}{|l|}{ Synergies (\$ million) } \\
\hline Mean & 79.65 & 90.54 & 65.86 & -24.68 & -0.21 \\
\hline Median & $27.97 * * *$ & $30.79 * * *$ & $26.74 * *$ & -4.05 & -0.67 \\
\hline Observations & 1618 & 904 & 714 & & \\
\hline \multicolumn{6}{|l|}{$D \_T F P$} \\
\hline Mean & $-0.029 * * *$ & $-0.035^{* * *}$ & $-0.022 * * *$ & 0.013 & 1.52 \\
\hline Median & $-0.003 * * *$ & 0.008 & $-0.015 * * *$ & $-0.023 *$ & 1.95 \\
\hline Observations & 4827 & 2545 & 2282 & & \\
\hline \multicolumn{6}{|l|}{$D \_R O A(\%)$} \\
\hline Mean & $-1.47 * * *$ & $-1.59 * * *$ & $-1.32 * * *$ & 0.27 & 1.59 \\
\hline Median & $-0.34 * * *$ & $-0.37 * * *$ & $-0.31 * * *$ & 0.06 & 1.62 \\
\hline Observations & 7011 & 3946 & 3065 & & \\
\hline
\end{tabular}

The table presents changes in deal performance surrounding the passage of SOX. The sample is 7747 completed U.S. acquisitions over the period January 1, 1993, to December 31, 2010 from SDC Platinum. Stock price data are from CRSP. $2 y r A B H R$ is the 2-year daily buy-and-hold return of the acquiring firm beginning one day following the acquisition effective date minus the return of a matched firm over the same period. Firms are matched by industry, year, size and book-to-market ratio from a universe of firms that have not been involved in any acquisition activity for a period of 3 years surrounding the deal effective date. Synergies is the total dollar gains for the bidder and the target from the transaction calculated as the market value of equity 6 trading days before the acquisition announcement date times the cumulated abnormal returns over an 11-day window surrounding the announcement date $(-5,+5)$ for each firm. $D \_T F P$ is the change in total factor productivity (TFP) from the end of the year preceding the acquisition announcement to the end of the year following the completion of the deal. Firm-year TFP data is from İmrohoroglu and Tuzel (2014). $D \_R O A$ is the difference in the return on assets of the acquiring firm from the end of the year preceding the acquisition announcement to the end of the year following the completion of the deal. Acquisitions with an announcement date after July 30, 2002 belong to the post-SOX period, otherwise they belong to the pre-SOX period. t-statistics are from the t-test of difference between means and $z$-statistics are from the Wilcoxon rank sum test for difference between the respective distributions. $* * *, * *$ and $*$ indicate statistical significance at the $1 \%, 5 \%$ and $10 \%$ levels respectively 


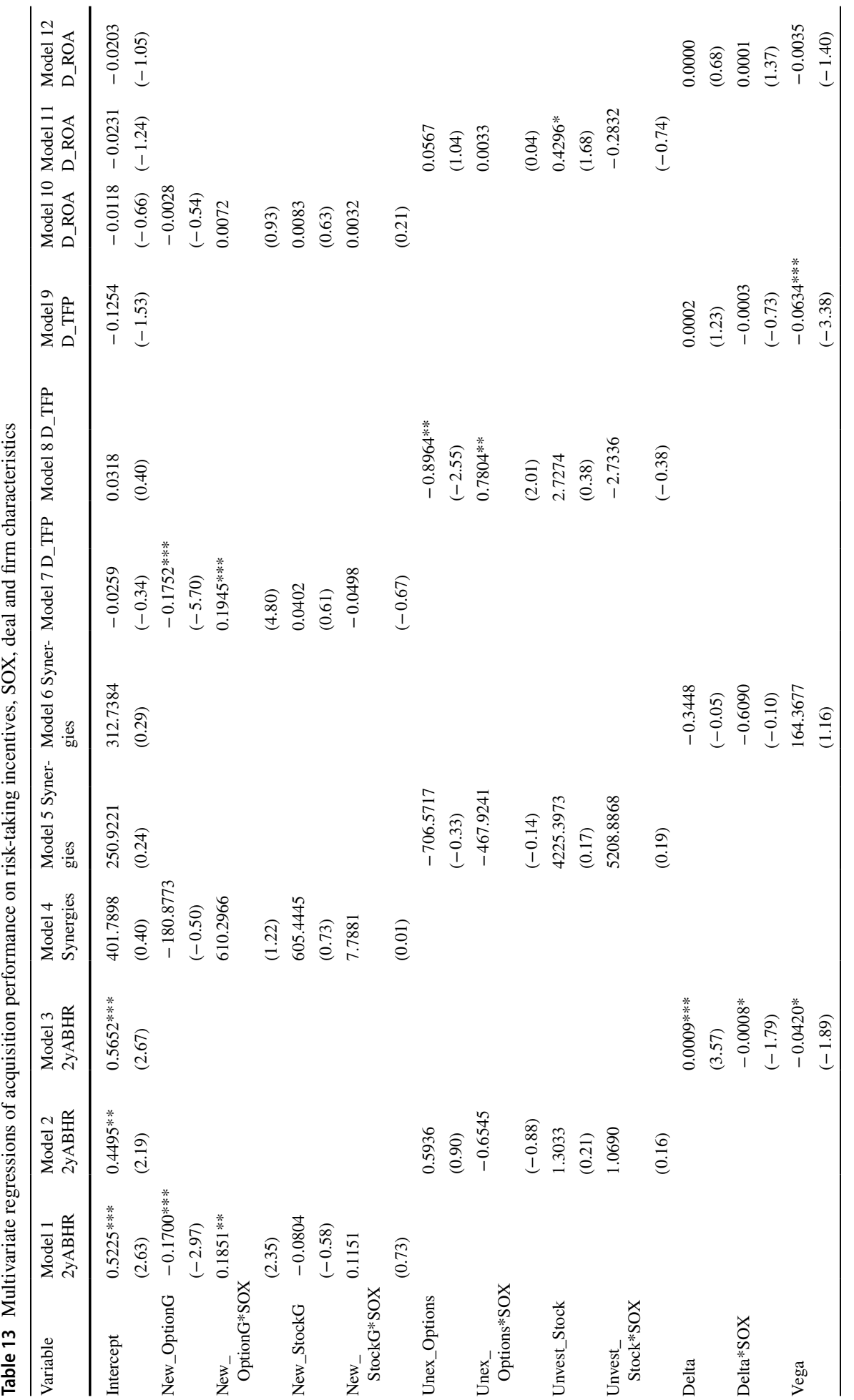




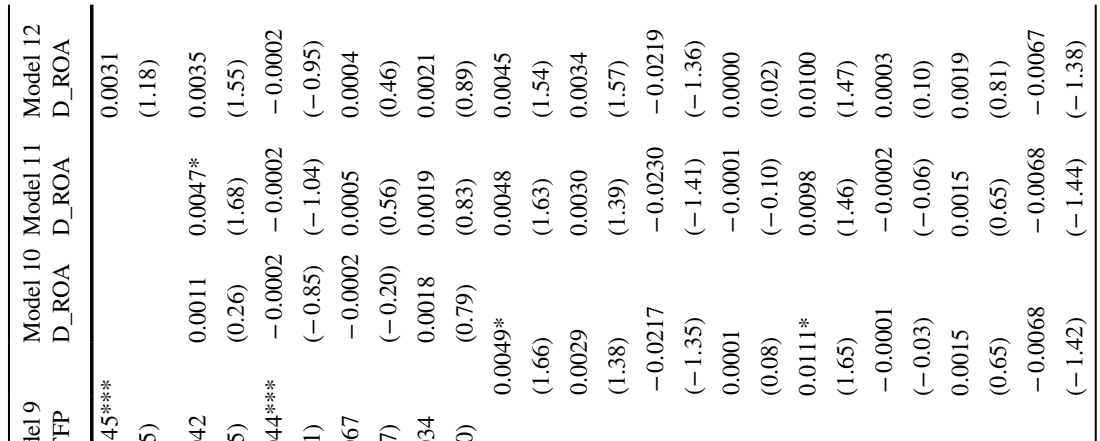

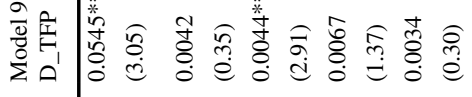

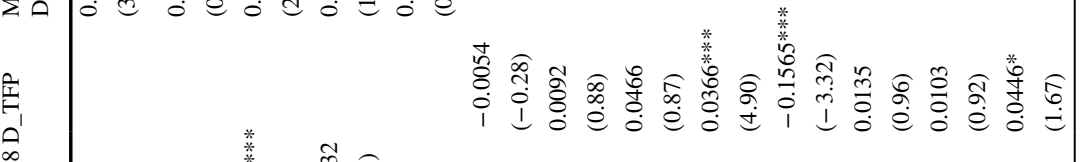

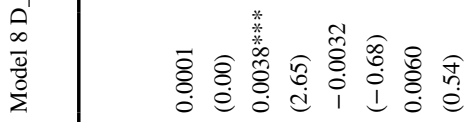

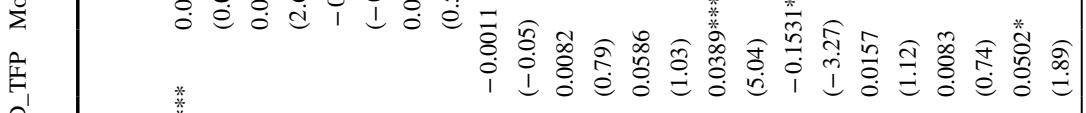

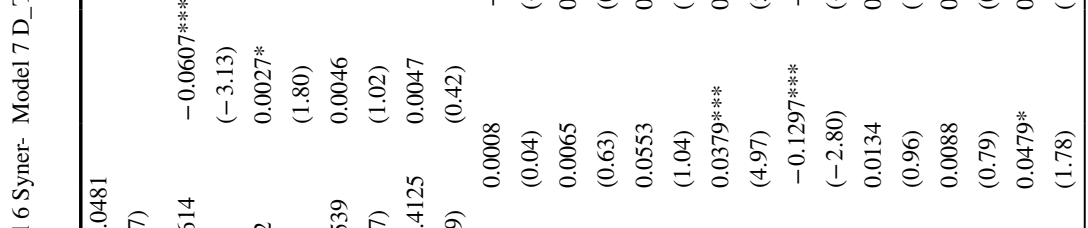

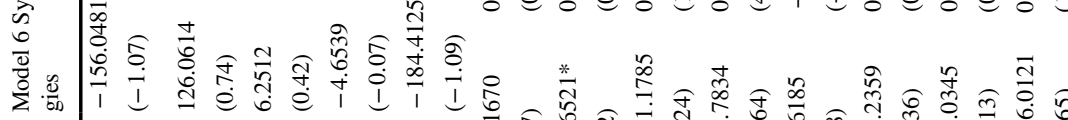

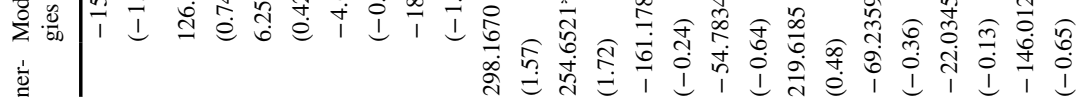

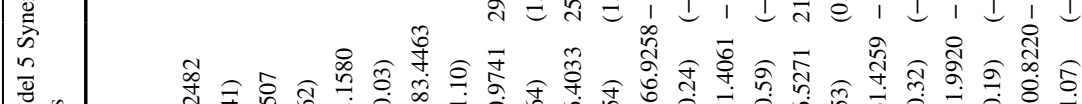

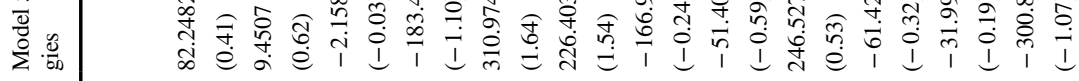

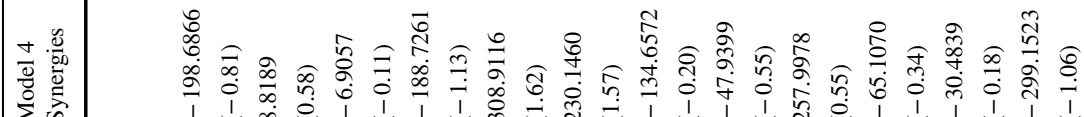

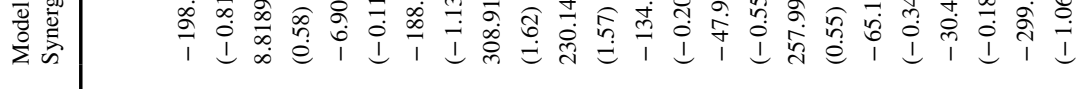

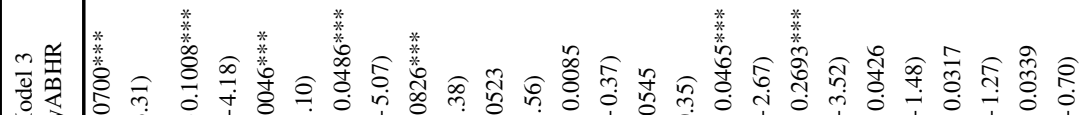 零 \\ 공

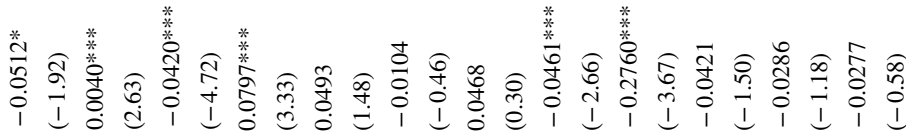

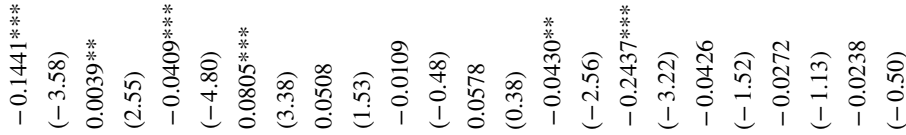

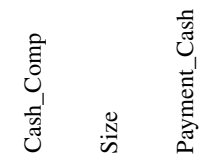 总

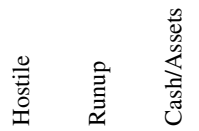

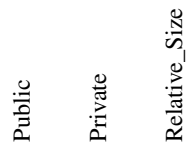




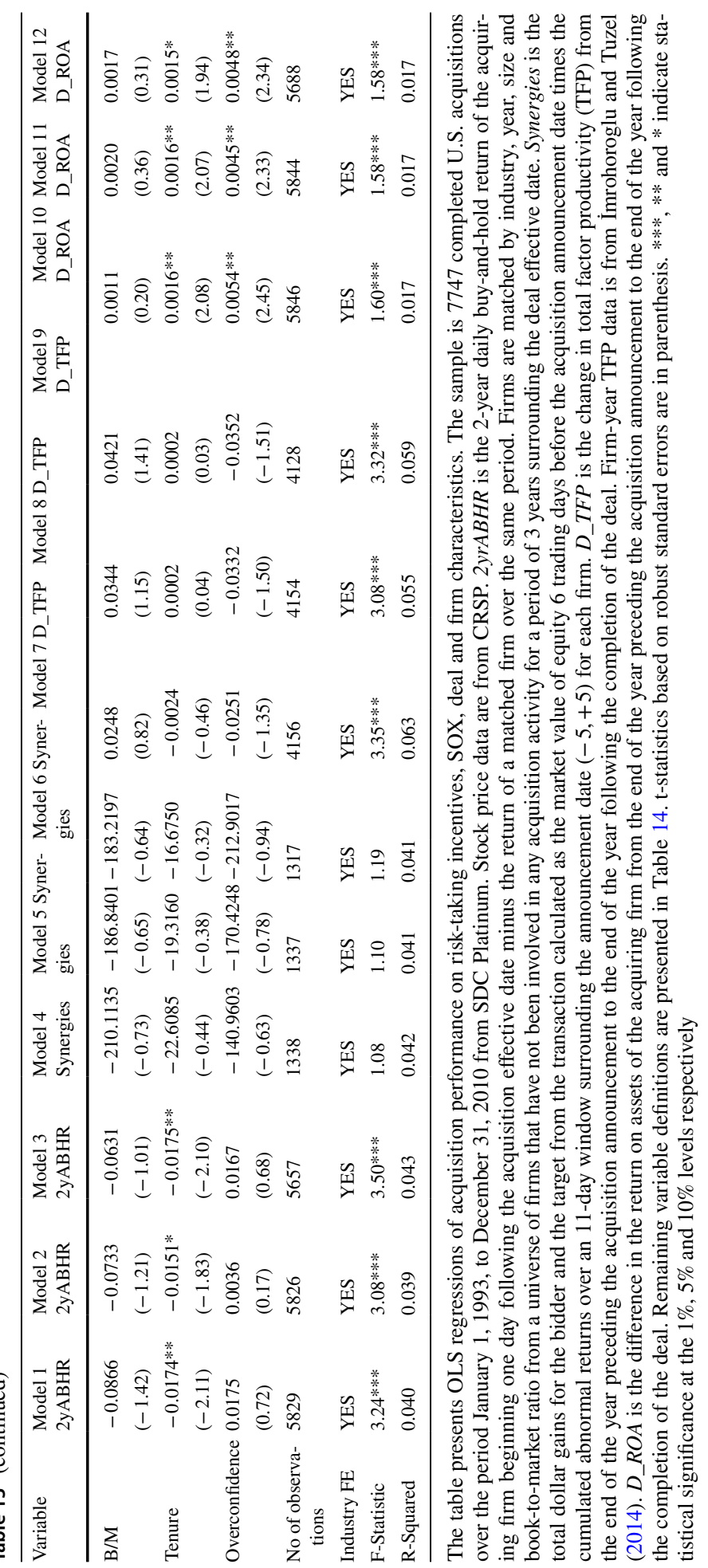




\section{Summary and conclusions}

Our study reveals an important weakening in the relation between incentive compensation and risk-taking activity after the passage of the Sarbanes-Oxley Act. While changes in acquisition risk can be partly explained by changes in the structure of executive compensation, our empirical analysis identifies a statistically significant change in the effect of incentive compensation on managerial behavior after the introduction of SOX. Prior to SOX, executives who receive a higher proportion of their compensation through equity-based incentives are more likely to engage in acquisitions that increase firm risk. However, SOX changed the way managers respond to equity incentives with some high-incentivized managers becoming more risk-averse after SOX.

When incentive compensation is disaggregated into its individual components, the change in managerial behavior is driven by the executives' option portfolio. On the other hand, common stock grants cannot explain differences in risk-taking activity between the pre- and post-SOX periods. Our results are robust to alternative definitions of firm risk, different specifications of managerial incentives, additional controls for changes in board governance surrounding SOX, and remain unchanged after controls for endogeneity.

Acquisitions are, in general, risky investment decisions. In a period characterized by higher personal costs and increased regulatory scrutiny, managers have responded to SOX in a value-enhancing manner. They make acquisition decisions that have a smaller impact on the volatility of their firm stock returns relative to the pre-SOX period benefiting, at the same time, shareholders in the long run. The positive impact on long-term stock price performance and total factor productivity has been transmitted through the same incentive mechanism that has been affected by the passage of SOX: the executives' option portfolio.

\section{Appendix}

See Tables 14 and 15 . 
Table 14 Variable definitions

Compensation variables

New_Grants

New_OptionG

New_StockG

Accum_Incentives

Unex_Options

Unvest_Stock

Delta

Vega

Cash_Comp

Pred_New_Grants

Pred_New_OptionG

Pred_New_StockG

Pred_Delta

Pred_Vega

Risk measures

D_Risk

D_Risk_AbR
The Black-Scholes fair value of new options and restricted stock grants awarded to the acquirer's top five executives as a percentage of their total compensation in the year preceding the acquisition announcement from ExecuComp

The fair value of new executive stock options awarded to the acquirer's top five executives as a percentage of their total compensation in the year preceding the acquisition announcement from ExecuComp

The fair value of restricted stock grants awarded to the acquirer's top five executives as a percentage of their total compensation in the year preceding the acquisition announcement from ExecuComp

The sum of unexercised stock options and unvested restricted stock held by the top five executives as a percentage of the total number of shares outstanding at the end of the year preceding the acquisition announcement from ExecuComp

The ratio of unexercised stock options held by the top five executives to the total number of shares outstanding at the end of the year preceding the acquisition announcement from ExecuComp

The ratio of unvested restricted stock grants held by the top five executives to the total number of shares outstanding at the end of the year preceding the acquisition announcement from ExecuComp

The dollar change in the wealth of top five executives for a $1 \%$ change in the firm's stock price in the year preceding the acquisition announcement from ExecuComp

The dollar change in the wealth of top five executives for a $1 \%$ change in the standard deviation of firm's stock returns in the year preceding the acquisition announcement from ExecuComp

The sum of salary and bonus payments to the top five executives scaled by total compensation in the year preceding the acquisition announcement from ExecuComp

The predicted value of new options and restricted stock grants awarded to the acquirer's top five executives as a percentage of their total compensation in the year preceding the acquisition announcement. Predicted values of equity incentives are estimated following the model of Core and Guay (1999)

The predicted value of new options grants awarded to the acquirer's top five executives as a percentage of their total compensation in the year preceding the acquisition announcement. Predicted values of stock option grants are estimated following the model of Core and Guay (1999)

The predicted value of restricted stock grants awarded to the acquirer's top five executives as a percentage of their total compensation in the year preceding the acquisition announcement. Predicted values of restricted stock grants are estimated following the model of Core and Guay (1999)

The predicted change in pay-performance sensitivity of the acquirer's top five executives from year $t-1$ to year $t$ where $t$ is the acquisition announcement date. Predicted values of pay-performance sensitivity are estimated following the model of Core and Guay (1999)

The predicted change in pay-risk sensitivity of the acquirer's top five executives from year $t-1$ to year $t$ where $t$ is the acquisition announcement date. Predicted values of pay-risk sensitivity are estimated following the model of Core and Guay (1999)

The change in the standard deviation of acquirer's stock return between 6 months following the effective date ( +1 to +126 days) and 6 months preceding the effective date ( -126 to -1 days) from CRSP

The change in the standard deviation of acquirer's abnormal stock returns between 6 months following the effective date $(+60$ to +185 days) and 6 months preceding the acquisition announcement date ( -185 to -60 days) from CRSP. Abnormal stock returns are calculated as the residual from the market model using the CRSP valueweighted index 
Table 14 (continued)

D_Risk_PSM $\begin{aligned} & \text { The volatility of acquirer's excess stock returns for a 6-month period following the } \\ & \text { effective date }(+60 \text { to }+185 \text { trading days) minus the volatility of acquirer's excess } \\ & \text { stock returns for a 6-month period preceding the announcement date }(-185 \text { to }-60 \\ & \text { trading days). Excess returns are calculated as the bidder's daily returns minus those } \\ & \text { of the propensity-score matched firm for the same period }\end{aligned}$

Performance measure 2yrABHR

Synergies

D_TFP

D_ROA

Deal characteristics SOX

SOX2002b

SOX2003

SOX2004

SOX2005

Internet_Crash

SFAS_123R

Financial_Crisis

Payment_Cash

Payment_Stock

Diversifying

Hostile

Public
The bidder's 2-year buy-and-hold daily returns following the acquisition effective date minus the 2-year buy-and-hold daily returns of the matched firm for the same time period from CRSP

The total dollar gains for the bidder and the target from the transaction calculated as the market value of equity 6 trading days before the acquisition announcement date times the cumulated abnormal returns over an 11-day window surrounding the announcement date $(-5,+5)$ for each firm. Cumulated abnormal returns are based on the market model using the CRSP value-weighted index

The change in total factor productivity (TFP) from the end of the year preceding the acquisition announcement to the end of the year following the completion of the deal. Firm-year TFP data is from İmrohoroglu and Tuzel (2014). Positive values indicate an improvement in TFP

The difference in the return on assets (ROA) of the acquiring firm from the end of the year preceding the acquisition announcement to the end of the year following the completion of the deal. Positive values indicate an improvement in operation performance

A dummy variable that takes the value of one if the acquisition announcement date is after the enactment of Sarbanes-Oxley Act (July 30,2002) and zero otherwise

A dummy variable that takes the value of one if the acquisition announcement date is within the period August 01, 2002-December 31, 2002 and zero otherwise

A dummy variable that takes the value of one if the acquisition announcement date is within the calendar year 2003 and zero otherwise

A dummy variable that takes the value of one if the acquisition announcement date is within the calendar year 2004 and zero otherwise

A dummy variable that takes the value of one if the acquisition announcement date is within the calendar year 2005 and zero otherwise

The decile ranking of stock price performance between August 1, 2000 and August 31, 2001 for firms with an acquisition announcement date during this period, and zero for acquisitions that take place outside of this period. Decile 1 corresponds to the best performing firms

A dummy variable set equal to one if the acquisition announcement is made in 2006 and zero otherwise

The decile ranking of stock price performance between January 1, 2007 and December 31, 2009 for firms with an acquisition announcement date during this period, and zero for acquisitions that take place outside of this period. Decile 1 corresponds to the best performing firms

A dummy variable that takes the value of one if the deal is financed entirely with cash and zero otherwise from SDC Platinum

A dummy variable that takes the value of one if the deal is financed only with equity and zero otherwise from SDC Platinum

A dummy variable that takes the value of one if the acquiring firm and the target operate in different industries and zero otherwise based on the Fama and French (1997) classification of 48 industries

A dummy variable that takes the value of one if the deal is characterized by SDC as hostile or unsolicited and zero otherwise

A dummy variable that takes the value of one if the target is a publicly listed firm and zero otherwise 
Table 14 (continued)

A dummy variable that takes the value of one if the target is a privately held firm and
zero otherwise
The ratio of the deal value reported in SDC Platinum to the market value of the acquir-
ing firm 4 weeks before the acquisition announcement date from CRSP
A dummy variable that takes the value of one if a firm has made an acquisition
announcement in a given year and zero otherwise

\section{Firm characteristics}

Size

Runup

Past_ABHR

Cash/Assets

ROA

Sales_Growth

D_Leverage

Leverage

$\mathrm{B} / \mathrm{M}$

$R \& D$

Net_PPE

CAPEX

$\mathrm{P} / \mathrm{E}$

NC_Working_Cap

Tenure

Overconfidence

CEO/Chairman

Indep_Directors

Audit_Indep
The natural logarithm of bidder's market value of equity 4 weeks before the acquisition announcement date from CRSP

The acquirer's buy-and-hold daily returns between 205 and 6 days before the acquisition announcement date minus the buy-and-hold daily returns of the matched firm for the same time period from CRSP

The market-adjusted buy-and-hold daily returns of the firm for the calendar year from CRSP. Market returns are from the CRSP value-weighted index

The acquirer's cash and cash equivalents to book value of total assets at the end of the year preceding the acquisition announcement from Compustat

The operating income of the acquiring firm before depreciation divided by book value of total assets at the end of the year preceding the acquisition announcement from Compustat

The logarithm of the ratio of bidder's sales in the year preceding the acquisition announcement $(\mathrm{t}-1)$ to sales in the previous year $(\mathrm{t}-2)$ from Compustat

The change in the ratio of acquirer's total debt to total assets from the end of the year preceding the acquisition announcement to the end of the year when the acquisition is announced from CRSP

Total debt to total assets at the end of the year preceding the acquisition announcement from Compustat

The book value of equity from Compustat divided by its market value at the end of the year preceding the acquisition announcement from CRSP

The acquirer's research and development expenditure to book value of total assets at the end of the year preceding the acquisition announcement from Compustat

The acquirer's net expenditure in property, plant and equipment to book value of total assets at the end of the year preceding the acquisition announcement from Compustat

The capital expenditures of the acquiring firm divided by book value of total assets at the end of the year preceding the acquisition announcement from Compustat

The ratio of the stock price to earnings per share at the end of the year preceding the acquisition announcement from CRSP/Compustat

Current assets minus current liabilities minus cash and cash equivalents standardized by book value of total assets at the end of the year preceding the acquisition announcement from Compustat

The number of months the CEO has served in this position at the time of the acquisition announcement from ExecuComp

The value per in-the-money vested option retained by the CEO from ExecuComp scaled by the stock price of the firm at the end of the fiscal year from Compustat. The value per in-the-money vested option is calculated as the value of all unexercised exercisable options retained by the CEO divided by the total number of these options from ExecuComp

A dummy variable that takes that value of one if the roles of CEO and Chairman of the acquiring firm are combined at the end of the year preceding the acquisition announcement and zero otherwise from ExecuComp

The number of independent directors divided by board size from BoardEx

The proportion of independent directors in the audit committee from BoardEx 
Table 15 Probit regressions of determinants of propensity to acquire

\begin{tabular}{|c|c|c|c|c|c|}
\hline Variable & Probit Model 1 & Probit Model 2 & Probit Model 3 & Probit Model 4 & Probit Model 5 \\
\hline Intercept & $\begin{array}{l}-2.0374 * * * \\
(-15.15)\end{array}$ & $\begin{array}{l}-2.0640 * * * \\
(-15.30)\end{array}$ & $\begin{array}{l}-2.5996 * * * \\
(-17.62)\end{array}$ & $\begin{array}{l}-2.5999 * * * \\
(-17.62)\end{array}$ & $\begin{array}{l}-2.0823 \text { *** } \\
(-14.48)\end{array}$ \\
\hline New_Grants & $\begin{array}{l}0.3754 * * * \\
(8.62)\end{array}$ & & & & \\
\hline New_OptionG & & $\begin{array}{l}0.4049 \text { *** } \\
(8.97)\end{array}$ & & & \\
\hline New_StockG & & $\begin{array}{l}0.2399 * * * \\
(3.30)\end{array}$ & & & \\
\hline Accum_Incentives & & & $\begin{array}{l}2.6158 * * * \\
(6.43)\end{array}$ & & \\
\hline Unex_Options & & & & $\begin{array}{l}2.5648 * * * \\
(6.19)\end{array}$ & \\
\hline Unvest_Stock & & & & $\begin{array}{l}3.8561 * \\
(1.92)\end{array}$ & \\
\hline Delta & & & & & $\begin{array}{l}0.0001 \\
(0.08)\end{array}$ \\
\hline Vega & & & & & $\begin{array}{l}0.0736^{* * * *} \\
(3.64)\end{array}$ \\
\hline Cash_Comp & $\begin{array}{l}0.0083 * * * \\
(2.63)\end{array}$ & $\begin{array}{l}0.0079 * * \\
(2.50)\end{array}$ & $\begin{array}{l}0.0023 \\
(0.71)\end{array}$ & $\begin{array}{l}0.0023 \\
(0.71)\end{array}$ & $\begin{array}{l}0.0025 \\
(0.73)\end{array}$ \\
\hline SOX & $\begin{array}{l}-0.0230 \\
(-1.10)\end{array}$ & $\begin{array}{l}-0.0058 \\
(-0.26)\end{array}$ & $\begin{array}{l}-0.0249 \\
(-1.19)\end{array}$ & $\begin{array}{l}-0.0262 \\
(-1.25)\end{array}$ & $\begin{array}{l}-0.0275 \\
(-1.29)\end{array}$ \\
\hline Size & $\begin{array}{l}0.0659 * * * \\
(7.30)\end{array}$ & $\begin{array}{l}0.0677 * * * \\
(7.46)\end{array}$ & $\begin{array}{l}0.1125^{* * *} \\
(11.84)\end{array}$ & $\begin{array}{l}0.1125^{* * * *} \\
(11.84)\end{array}$ & $\begin{array}{l}0.0811^{* * *} \\
(8.57)\end{array}$ \\
\hline Past_ABHR & $\begin{array}{l}0.0223^{*} \\
(1.70)\end{array}$ & $\begin{array}{l}0.0226^{*} \\
(1.73)\end{array}$ & $\begin{array}{l}0.0122 \\
(0.92)\end{array}$ & $\begin{array}{l}0.0121 \\
(0.91)\end{array}$ & $\begin{array}{l}0.0202 \\
(1.52)\end{array}$ \\
\hline Cash/Assets & $\begin{array}{l}0.0978 \\
(1.40)\end{array}$ & $\begin{array}{l}0.0829 \\
(1.19)\end{array}$ & $\begin{array}{l}0.1502 * * \\
(2.17)\end{array}$ & $\begin{array}{l}0.1526 * * \\
(2.20)\end{array}$ & $\begin{array}{l}0.1715^{* *} \\
(2.46)\end{array}$ \\
\hline $\mathrm{BM}$ & $\begin{array}{l}-0.1334 * * * \\
(-3.12)\end{array}$ & $\begin{array}{l}-0.1271 * * * \\
(-3.00)\end{array}$ & $\begin{array}{l}-0.1291 * * * \\
(-2.97)\end{array}$ & $\begin{array}{l}-0.1295 * * * \\
(-2.98)\end{array}$ & $\begin{array}{l}-0.1420 * * * \\
(-3.18)\end{array}$ \\
\hline ROA & $\begin{array}{l}0.0795 \\
(0.82)\end{array}$ & $\begin{array}{l}0.0839 \\
(0.87)\end{array}$ & $\begin{array}{l}0.0185 \\
(0.19)\end{array}$ & $\begin{array}{l}0.0183 \\
(0.19)\end{array}$ & $\begin{array}{l}-0.0706 \\
(-0.72)\end{array}$ \\
\hline Sales_Growth & $\begin{array}{l}0.6279 * * * \\
(6.64)\end{array}$ & $\begin{array}{l}0.6201 * * * \\
(6.57)\end{array}$ & $\begin{array}{l}0.6451 * * * \\
(6.75)\end{array}$ & $\begin{array}{l}0.6460 * * * \\
(6.77)\end{array}$ & $\begin{array}{l}0.6876^{* * * *} \\
(7.07)\end{array}$ \\
\hline Leverage & $\begin{array}{l}-0.1877 * * \\
(-2.55)\end{array}$ & $\begin{array}{l}-0.1835^{* *} \\
(-2.49)\end{array}$ & $\begin{array}{l}-0.2059 * * * \\
(-2.78)\end{array}$ & $\begin{array}{l}-0.2059 * * * \\
(-2.78)\end{array}$ & $\begin{array}{l}-0.1979 * * * \\
(-2.64)\end{array}$ \\
\hline $\mathrm{P} / \mathrm{E}$ & $\begin{array}{l}-0.0015 \\
(-0.27)\end{array}$ & $\begin{array}{l}-0.0016 \\
(-0.29)\end{array}$ & $\begin{array}{l}-0.0014 \\
(-0.25)\end{array}$ & $\begin{array}{l}-0.0014 \\
(-0.25)\end{array}$ & $\begin{array}{l}-0.0016 \\
(-0.29)\end{array}$ \\
\hline NC_Working_Cap & $\begin{array}{l}0.0827 \\
(1.27)\end{array}$ & $\begin{array}{l}0.0732 \\
(1.12)\end{array}$ & $\begin{array}{l}0.0810 \\
(1.25)\end{array}$ & $\begin{array}{l}0.0821 \\
(1.26)\end{array}$ & $\begin{array}{l}0.0736 \\
(1.12)\end{array}$ \\
\hline Overconfidence & $\begin{array}{l}0.1677 * * * \\
(5.34)\end{array}$ & $\begin{array}{l}0.1626 * * * \\
(5.18)\end{array}$ & $\begin{array}{l}0.1643 * * * \\
(5.21)\end{array}$ & $\begin{array}{l}0.1647 * * * \\
(5.21)\end{array}$ & $\begin{array}{l}0.2034 * * * \\
(6.17)\end{array}$ \\
\hline Chi-Square & $563.88 * * *$ & $572.76^{* * *}$ & $525.79 * * *$ & $526.08 * * *$ & $502.38 * * *$ \\
\hline Observations & 21,072 & 21,072 & 21,062 & 21,062 & 20,576 \\
\hline
\end{tabular}


Table 15 (continued)

The table presents the results of probit regressions where the dependent variable, Acquisition, takes the value of one if a firm makes an acquisition announcement in a given year and zero otherwise for a panel of non-financial firm years with available data in ExecuComp. Past_ABHR is the market-adjusted buy-andhold daily returns of the firm over the calendar year from CRSP. Market returns are from the CRSP valueweighted index. $B / M$ is the book value of equity divided by market value. $P / E$ is the ratio of the stock price to earnings per share from. NC_Working_Cap is current assets minus current liabilities minus cash and cash equivalents standardized by book value of total assets. Definitions of all remaining variables are described in Table 14. Compensation and control variables are defined at the year before the acquisition announcement. z-statistics, based on standard errors clustered at the firm level, are reported in parentheses. ***, **, and $*$ indicate statistical significance at the $1 \%, 5 \%$ and $10 \%$ level respectively

Supplementary Information The online version contains supplementary material available at https://doi. org/10.1007/s11156-021-01028-6.

Open Access This article is licensed under a Creative Commons Attribution 4.0 International License, which permits use, sharing, adaptation, distribution and reproduction in any medium or format, as long as you give appropriate credit to the original author(s) and the source, provide a link to the Creative Commons licence, and indicate if changes were made. The images or other third party material in this article are included in the article's Creative Commons licence, unless indicated otherwise in a credit line to the material. If material is not included in the article's Creative Commons licence and your intended use is not permitted by statutory regulation or exceeds the permitted use, you will need to obtain permission directly from the copyright holder. To view a copy of this licence, visit http://creativecommons.org/licenses/by/4.0/.

\section{References}

Agrawal A, Mandelker G (1987) Managerial incentives and corporate investment and financing decisions. J Finance 42(4):823-838

Aktas N, de Bodt E, Roll R (2013) Learning from repetitive acquisitions: evidence from the time between deals. J Finance Econ 108(1):99-117

Arping S, Sautner Z (2013) Did SOX Section 404 make firms less Opaque? Evidence from cross-listed firms. Contemp Account Res 30(3):1133-1165

Banerjee S, Humphery-Jenner M, Nanda V (2015) Restraining overconfident CEOs through improved governance: evidence from the Sarbanes-Oxley Act. Rev Financial Stud 28(10):2812-2858

Banerjee S, Humphery-Jenner M, Nanda V, Tham M (2018) Executive overconfidence and securities class actions. J Financial Quant Anal 53(6):2685-2719

Barber BM, Lyon JD (1997) Detecting long-run abnormal returns: the empirical power and specification of test statistics. J Finance Econ 43(3):341-372

Bargeron LL, Lehn KM, Zutter CJ (2010) Sarbanes-Oxley and corporate risk-taking. J Account Econ 49(1-2):34-52

Bebchuk L, Cohen A, Ferrell A (2009) What matters in corporate governance? Rev Financial Stud 22(2):783-827. https://doi.org/10.1093/rfs/hhn099

Bennett RL, Güntay L, Unal H (2015) Inside debt, bank default risk, and performance during the crisis. J Financial Intermed 24(4):487-513

Benson BW, James HL, Park JC (2019) Heterogeneity in the effect of managerial equity incentives on firm value. Finance Rev 54(3):583-638

Berger PG, Ofek E, Yermack DL (1997) Managerial entrenchment and capital structure decisions. J Finance 52(4):1411-1438

Bhagat S, Bolton B (2008) Corporate governance and firm performance. J Corp Finance 14(1):257-273

Bhagat S, Bolton B (2019) Corporate governance and firm performance: the sequel. J Corp Finance 58(1):142-168

Bi XG, Gregory A (2011) Stock market driven acquisitions versus the Q theory of takeovers: the UK evidence. J Bus Finance Account 38(5-6):628-656 
Billett MT, Mauer DC, Zhang Y (2010) Stockholder and bondholder wealth effects of CEO incentive grants. Finance Manag 39(2):463-487

Billett MT, Qian Y (2008) Are overconfident CEOs born or made? Evidence of self-attribution bias from frequent acquirers. Manag Sci 54(6):1037-1051

Black F, Scholes M (1973) The pricing of options and corporate liabilities. J Polit Econ 81(3):637-654

Bloomfield MJ (2021) The asymmetric effect of reporting flexibility on priced risk. J Account Res 59(3):867-910

Boone JP, Khurana IK, Raman KR (2011) Investor pricing of CEO equity incentives. Rev Quant Finance Account 36(3):417-435

Borisova G, John K, Salotti V (2013) The value of financing through cross-border asset sales: shareholder returns and liquidity. J Corp Finance 22:320-344

Boulton JT, Braga-Alves MV, Schlingemann FD (2014) Does equity-based compensation make CEOs more acquisitive? J Financial Res 37(3):267-294

Bouwman CHS, Fuller K, Nain AS (2009) Market valuation and acquisition quality: empirical evidence. Rev Financial Stud 22(2):487-517

Bradley M, Desai A, Kim EH (1988) Synergistic gains from corporate acquisitions and their division between the stockholders of acquirer and acquiring firms. J Finance Econ 21(1):3-40

Brick IE, Palmon O, Wald JK (2006) CEO compensation, director compensation, and firm performance: evidence of cronyism? J Corp Finance 12(3):403-423

Brockman P, Martin X, Unlu E (2010) Executive compensation and the maturity structure of corporate debt. J Finance 65(3):1123-1161

Brown LD, Lee Y (2007) The impact of SFAS 123R on changes in option-based compensation. Working paper, Georgia State University

Carter ME, Lynch LJ, Zechman SLC (2009) Changes in bonus contracts in the post-Sarbanes-Oxley era. Rev Account Stud 14(4):480-506

Chang H, Choy HL, Wan KM (2012) Effect of the Sarbanes-Oxley act on CEO's stock ownership and payperformance sensitivity. Rev Quant Finance Account 38(2):177-207

Chava S, Purnanandam A (2010) CEOs versus CFOs: incentives and corporate policies. J Finance Econ 97(2):263-278

Chen Y, Gul F, Veeraraghavan M, Zolotoy L (2015) Executive equity risk-taking incentives and audit pricing. Account Rev 90(6):2205-2234

Chhaochharia V, Grinstein Y (2009) CEO compensation and board structure. J Finance 64(1):231-261

Cohen DA, Dey A, Lys TZ (2013) Corporate governance reform and executive incentives: implications for investments and risk-taking. Contemp Account Res 30(4):1296-1332

Coles JL, Daniel ND, Naveen L (2006) Managerial incentives and risk-taking. J Finance Econ 79(2):431-468

Coles JL, Daniel ND, Naveen L (2014) Co-opted boards. Rev Financial Stud 27(6):1751-1796

Core J, Guay W (1999) The use of equity grants to manage optimal equity incentive levels. J Account Econ 28(2):83-242

Core J, Guay W (2002) Estimating the value of employee stock option portfolios and their sensitivities to price and volatility. J Account Res 40(3):613-630

Croci E, Petmezas D (2015) Do risk-taking incentives induce CEO to invest? Evidence form acquisitions. J Corp Finance 32(1):1-23

Datta S, Iskander-Datta M, Raman K (2001) Executive compensation and corporate acquisition decisions. J Finance 56(6):2299-2336

Dechow PM, Hutton AP, Sloan RG (1996) Economic consequences of accounting for stock-based compensation. J Account Res 34(3):1-20

Dicks DL (2012) Executive compensation and the role for corporate governance regulation. Rev Financial Stud 25(6):1971-2004

Draper P, Paudyal K (2006) Acquisitions: private versus public. Eur Finance Manag 12(1):57-80

Duchin R, Schmidt B (2013) Riding the merger wave: uncertainty, reduced monitoring, and bad acquisitions. J Finance Econ 107(1):69-88

Fama EF, French KR (1997) Industry costs of equity. J Finance Econ 43(2):153-193

Flor CR, Frimor H, Munk C (2014) Options in compensation: promises and pitfalls. J Account Res 52(3):703-732

Francis BB, Hasan I, Hunter DM, Zhu Y (2017) Do managerial risk-taking incentives influence firms' exchange rate exposure? J Corp Finance 46(1):154-169

Gao H, Zhang J (2019) SOX Section 404 and corporate innovation. J Financial Quant Anal 54(2):759-787

Golubov A, Petmezas D, Travlos NG (2012) When It pays to pay your investment banker: new evidence on the role of financial advisors in M\&As. J Finance 67(1):271-311 
Gompers P, Ishii J, Metrick A (2003) Corporate governance and equity prices. Q J Econ 118(1):107-155

Gormley TA, Matsa DA, Milbourn T (2013) CEO compensation and corporate risk: evidence from a natural experiment. J Account Econ 56(2-3):79-101

Guay W (1999) The sensitivity of CEO wealth to equity risk: an analysis of the magnitude and determinants. J Finance Econ 53(1):43-71

Guo L, Lach P, Mobbs S (2015) Tradeoffs between internal and external governance: evidence from exogenous regulatory shocks. Finance Manag 44(1):81-114

Hagendorff J, Vallascas F (2011) CEO pay incentives and risk-taking: evidence from bank acquisitions. J Corp Finance 17(4):1078-1095

Harford J (1999) Corporate cash reserves and acquisitions. J Finance 62(2):1969-1997

Harford J, Li K (2007) Decoupling CEO wealth and firm performance: the case of acquiring CEOs. J Finance 62(2):917-949

Hansen RG (1987) A theory of choice of exchange medium in mergers and acquisitions. J Finance 60(1):75-95

He Z (2012) Dynamic compensation contracts with private savings. Rev Financial Stud 21(3):1371-1401

Hege U, Hutson E, Laing E (2021) Mandatory governance reform and corporate risk management. J Corp Finance 68(1):1-32

Hirshleifer D, Suh Y (1992) Risk, managerial effort, and project choice. J Financial Intermed 2(3):308-345

İmrohoroglu A, Tuzel S (2014) Firm-level productivity, risk, and return. Manag Sci 60(8):2073-2090

Jensen MC (1988) Takeovers: their causes and consequences. J Econ Perspect 2(1):21-48

Jiménez-Angueira CE, Stuart NV (2015) Relative performance evaluation, pay-for-luck, and double-dipping in CEO compensation. Rev Quant Finance Account 44:701-732

John TA, John K (1993) Top-management compensation and capital structure. J Finance 48(3):949-974

Kang Q, Liu Q, Qi R (2010) The Sarbanes-Oxley Act and corporate investment: a structural assessment. J Finance Econ 96(2):291-305

Kravet TD (2014) Accounting conservatism and managerial risk-taking: corporate acquisitions. J Account Econ 57(2-3):218-240

Kwon SS, Yin J, Ndubizu GA (2019) Asymmetric sensitivity of executive bonus compensation to earnings and the effect of regulatory changes. Rev Quant Finance Account 53:845-869

Leuz C, Wysocki PD (2016) The economics of disclosure and financial reporting regulation: evidence and suggestions for future research. J Account Res 54(2):525-622

Linck JS, Netter JM, Yang T (2009) The effects and unintended consequences of the Sarbanes-Oxley Act on the supply and demand for directors. Rev Financial Stud 22(8):3287-3328

Liu Y, Gan H, Karim K (2020) Corporate risk-taking after adoption of compensation clawback provisions. Rev Quant Finance Account 54:617-649

Loughran T, Vijh A (1997) Do long-term shareholders benefit from corporate acquisitions? J Finance 52(5):1765-1790

Malmendier U, Tate G (2008) Who makes acquisitions? CEO overconfidence and the market's reaction. J Finance Econ 89(1):20-43

Masulis RW, Wang C, Xie F (2007) Corporate governance and acquirer returns. J Finance 62(4):1851-1889

Merton RC (1973) Theory of rational option pricing. Bell J Econ Manag Sci 4(1):141-183

Moeller SB, Schlingemann FP, Stulz RM (2004) Firm size and the gains from acquisitions. J Finance Econ 73(2):201-228

Moeller SB, Schlingemann FP, Stulz RM (2005) Wealth destruction on a massive scale? A study of acquiring-firm returns in the recent merger wave. J Finance 60(2):757-782

Morck R, Shleifer A, Vishny RW (1990) Do managerial objectives drive bad acquisitions? J Finance 45(1):31-48

Nam J, Ottoo RE, Thornton JH Jr (2003) The effect of managerial incentives to bear risk on corporate capital structure and R\&D investment. Financial Rev 38(1):77-101

Nejadmalayeri A, Nishikawa T, Rao RP (2013) Sarbanes-Oxley Act and corporate credit spreads. J Bank Finance 37(8):2991-3006

Nohel T, Todd S (2005) Compensation for managers with career concerns: the role of stock options in optimal contracts. J Corp Finance 11(1-2):229-251

Olley S, Pakes A (1996) The dynamics of productivity in the telecommunications equipment industry. Econometrica 64(6):1263-1297

Officer MS (2007) The price of corporate liquidity: acquisition discount for unlisted targets. J Finance Econ 83(3):571-598

Parrino R, Poteshman AM, Weisbach MS (2005) Measuring investment distortions when risk-averse managers decide whether to undertake risky projects. Finance Manag 34(1):21-60 
Pryshchepa O (2021) Disciplining entrenched managers through corporate governance reform: implications for risk-taking behavior. Corp Gov Int Rev (forthcoming)

Rogers DA (2002) Does executive portfolio structure affect risk management? CEO risk-taking incentives and corporate derivatives usage. J Bank Finance 26(2-3):271-295

Shadab HB (2008) Innovation and corporate governance: the impact of Sarbanes-Oxley. Univ Pa J Bus Employment Law 10(4):955-1008

Shen CH, Zhang H (2013) CEO risk incentives and firm performance following R\&D increases. J Bank Finance 37(4): 1176-1194

Shleifer A, Vishny R (2003) Stock market driven acquisitions. J Finance Econ 70(3):295-311

Smith CW, Stulz R (1985) The determinants of firms' hedging policies. J Financial Quant Anal 20(4):391-405

Smith CW, Watts RL (1982) Incentive and tax effects of executive compensation plans. Aust J Manag 7(2):139-157

Smith CW Jr, Watts RL (1992) The investment opportunity set and corporate financing, dividend, and compensation policies. J Finance Econ 32(3):263-292

Spiess DK, Affleck-Graves J (1999) The long-run performance of stock returns following debt offerings. J Finance Econ 54(1):45-73

Tang H (2014) Are CEO stock option grants optimal? Evidence from family firms and non-family firms around the Sarbanes-Oxley Act. Rev Quant Finance Account 42(2):251-292

Travlos NG (1987) Corporate takeover bids, methods of payment, and bidding firms' stock returns. J Finance 42(4):943-963

Uysal VB (2011) Deviation from the target capital structure and acquisition choices. J Finance Econ 102(3):602-620

Vallascas F, Hagendorff J (2013) CEO Bonus compensation and bank default risk: evidence from the U.S. and Europe. Financial Mark Inst Instrum 22(2):47-89

Welch I (2004) Capital structure and stock returns. J Polit Econ 112(1):106-132

Wintoki MB (2007) Corporate boards and regulation: the effect of the Sarbanes-Oxley Act and the exchange listing requirements on firm value. J Corp Finance 13(2-3):229-250

Yermack D (1995) Do corporations award CEO stock options effectively? J Finance Econ 39(2-3):237-269

Yermack D (2006) Golden handshakes: separation pay for retired and dismissed CEOs. J Account Econ 41(3):237-256

Yung C, Colak G, Wang W (2008) Cycles in the IPO market. J Finance Econ 89(1):192-208

Zhao J (2013) Entrenchment or incentive? CEO employment contracts and acquisition decisions. J Corp Finance 22(1):124-152

Publisher's Note Springer Nature remains neutral with regard to jurisdictional claims in published maps and institutional affiliations. 